\title{
How important are banks for development? National banks in the United States 1870-1900
}

\author{
Scott L. Fulford*
}

December 2014

\begin{abstract}
Do banks matter for growth and how? This paper examines the effects of national banks in the United States from 1870-1900. I use the discontinuity in entry caused by a large minimum size requirement to identify the effects of banking. For the counties on the margin between getting a bank and not, gaining a bank increased production per person by $10 \%$. National banks in rural areas improved agriculture over manufacturing, moving counties towards geographic comparative advantage. Since these banks made few long-term loans, the evidence suggests that the provision of working capital and liquidity matter for growth.
\end{abstract}

JEL classification: O16, G21

Keywords: National banks, commercial banking, financial development, growth

*Boston College Department of Economics, 140 Commonwealth Ave, Chestnut Hill, MA 02467; email: scott.fulford@bc.edu. I thank Shahed Kahn for his help entering and checking the national bank accounts, Mashfiqur Kahn for his help cross-checking, Perry Mehrling for his suggestions on the early banking literature, and Don Cox and Fabio Schiantarelli for their rhetorical good taste. This paper previously circulated under the title "Gilded or Gold? National Banks and Development in the United States 1870-1900." The paper has benefited from the thoughtful comments from seminar participants at Boston College, the Green Line Macro Meeting, the University of Toronto, the EIEF, the IFS, Brown University, and the NBER/Philadelphia Fed Macroeconomics across Time and Space conference. 


\section{Introduction}

There is a growing consensus that financial development contributes to growth both internationally and within nations. ${ }^{1}$ Yet since financial institutions typically go where they expect to make the most profits, it is difficult to determine just how important they are for growth. Moreover, since financial institutions typically do many things and may alleviate many different types of constraints, it is still unclear which financial services matter for growth.

Understanding the importance of financial institutions is crucial for both developed and developing economies. As developed countries seek the appropriate balance for financial regulation whether by increasing capital requirements (Admati and Hellwig, 2013) or by putting restrictions on certain activities, it is vital to understand the likely cost of regulations. Some services and institutions may be very valuable, and restricting them too much may harm growth; others may not be important for growth, but may add to risk, and so should be strictly regulated. In developing countries new services outside of traditional banking and financial markets are being offered to the poor. Which services and institutions should be subsidized and encouraged, and which should be carefully regulated and restricted, depends on their effects.

This paper examines a period in United States history of rapid financial, economic and geographic growth. From 1870-1900 the US expanded economically and geographically, settling its vast interior. National banks-banks chartered and regulated by the federal governmentexpanded with the rest of the country and were by far the most important financial institutions in the period. National banks could issue money directly in the form of bank notes and were central

\footnotetext{
${ }^{1}$ The recent cross-country literature starts with King and Levine (1993).Levine (2005) provides a summary crosscountry literature. In Italy Guiso, Sapienza, and Zingales (2004) find that local financial institutions aid growth, Benfratello, Schiantarelli, and Sembenelli (2008) show they matter for process innovation, but have little impact on product innovation, and Pascali (2011) examines the long term importance of banks. Rajan and Zingales (1998) show industries with greater need of external finance grow faster in countries with more developed financial markets. In developing countries Burgess and Pande (2005) and Fulford (2013) examine the experience of India during its large expansion of branch banking in the 1970s and 1980s. Kaboski and Townsend (2011) and Townsend and Ueda (2006) examine expansions of credit in Thailand.
} 
to the flow of funds that accompanied the vast increase in internal trade during the period.

To analyze the effects of these banks, I create a rich new data set which gives the exact geographic location and size of every national bank in 1870, 1880, 1890, and 1900. Charged with regulating the national banks and the money they issued, the Comptroller of the Currency collected and published the balance sheet of every national bank each year. Since national banks were not allowed to branch, the place of business listed in the accounts allows me to locate each bank precisely and to examine how much local financial development mattered. ${ }^{2}$

Concerned with the stability of the money supply, Congress required national banks to have a large minimum dollar amount of equity, called capital stock in the banking parlance of the day. Unlike the minimum capital-asset ratio typically required today, the large minimum total size meant that banks were limited in where they could enter profitably; not every county could support a bank of the minimum size, and many banks opened with exactly the minimum amount of capital stock. Combined with the no-branching rule, the constraint was binding. For example, when Congress loosened the minimum size in 1900, hundreds of smaller banks opened in just two years and nearly a thousand within the decade. I introduce and estimate a simple model of constrained bank entry using the minimum capital stock constraint. The estimates suggests that banks were still willing to open even when pushed to have more than double their profit maximizing equity. Even banks unconstrained by the minimum still had capital stock of more than $20 \%$ of their assets, far higher than banks today. Because of their high equity and limits on their lending activities, national banks rarely failed, even during the worst of the period's several financial crises (Wicker, 2000). While one should be careful drawing conclusions about modern banking from these estimates, they do suggest that banks can still open and provide valuable financial services even with much higher

\footnotetext{
${ }^{2}$ See Calomiris (2000, pp. 1-92) for the origins of the no-branching rule, and its costs in terms of stability and interregional integration in comparison to other countries. Examining a period when some of the strict limitations on branching used in this paper were relaxed, Jayaratne and Strahan (1996) find positive effects from allowing interstate branching.
} 
capital requirements.

How important were these banks for the real economy? Simply comparing areas that had banks with those that did not does not identify the effect of banking, since counties where banks want to enter are also likely to be areas of high economic activity or may grow quickly in the future. The minimum size requirement constrained entry, and so banks did not enter many areas that otherwise could have profitably supported a smaller bank. The underlying discontinuity in entry creates a discontinuity in the effect of banking. Some counties had significantly more banking than they would have received if banks were allowed to open at their optimum endogenous size; others had much less since smaller banks could not open. Reduced form estimates that compare neighboring counties, or compare counties that get a bank this decade with counties that get a bank the next decade, suggest that getting a bank of the minimum size increases production per person between 6 and $11 \%$.

To more precisely estimate the causal effects of these banks, I combine the estimates of bank entry with the discontinuity of entry induced by the minimum capital stock requirement. The estimates of bank entry using the panel provide information about the distribution of what banks would have liked to do in each county if they could enter freely. This distribution suggests, for example, in which counties banks were likely just barely willing to enter. In 1860, before national banks existed, such counties produced similar amounts to counties that just barely did not get a bank. Estimating using the full distribution from 1870 to 1900, for the marginal rural county gaining a bank of the minimum size increased production per person by $10.1 \%$.

Although the national banks engaged in most of the other functions of modern banks, they were not generally making long-term investments, and in particular could not take mortgages as collateral. Banking experts at the time considered that limitation particularly problematic for farmers who could not use their major asset, land, as collateral (Wright, 1922, pp. 46-70). Instead, these 
banks helped provided liquidity and working capital as well as risk pooling (see section 2 for more on the role of these banks). They also played an important role in the payments system through their correspondent networks (James, 1978, pp. 97-124).

Given that these banks were limited in their ability to make long-term loans and could not take land as collateral, one might think that they would have only a limited impact on agriculture. Yet for marginal counties in rural areas gaining a bank tended to shift production towards agriculture, despite the rapid rise in manufacturing over the period and the limitations for national banks on taking mortgages. The share of manufacturing in production for such counties falls because agricultural production increases far faster than manufacturing. The nature of the discontinuity means that the treatment effect only applies to counties in rural areas at the margin between getting a bank and not; the effects of national banks may have been different in urban areas. The pattern suggests that by aiding farmers or merchants with working capital and so facilitating trade, national banks helped counties move towards comparative advantage.

While the focus of much of financial development theory has been on how financial institutions fund new investments, the working capital, liquidity, and payments services of banks or other financial institutions may be equally or even more important. ${ }^{3}$ Recent empirical work has also suggested the importance of working capital and the availability of liquidity for small enterprises in urban areas of developing countries (Banerjee et al., 2013; de Mel, McKenzie, and Woodruff, 2008). Yet finance for working capital is crucial even in advanced economies, whether it is trade finance for exports (Amiti and Weinstein, 2009) or trade credit from other firms (Ng, Smith, and Smith, 1999).

\footnotetext{
${ }^{3}$ The distinction between funding a new investment and providing the working capital to either producers or intermediaries to get goods to market and payment clearing is perhaps subtle, but it seems clear that both rhetoric and modeling focus on funding investments rather than commerce. Aghion and Bolton (1997) present one version of the constrained entrepreneur. The entrepreneur might be making a human capital investment as in Banerjee and Newman (1993) or in Galor and Zeira (1993) the entrepreneur is someone deciding on an occupational choice. Galor and Moav (2004) provide an even more nuanced growth story, with similar underlying choices. In Greenwood and Jovanovic (1990) and Townsend and Ueda (2006) the entrepreneur faces a risky high return, or a safe low return investment, and financial markets bring diversification.
} 
Distance to financial institutions still matters in developed countries as well (Cetorelli and Strahan, 2006; Guiso, Sapienza, and Zingales, 2004), although improved communication technology may have diminished the importance of distance somewhat (Petersen and Rajan, 2002).

\section{National banks in the Gilded Age}

This section gives a brief description of the financial institutions of the period, the sources and construction of the data, and provides some descriptive statistics. Fulford (2011) provides greater detail about the period, the early literature on national banks, and more recent literature on the period which has focused on the integration of financial markets (Binder and Brown, 1991; Davis, 1965; James, 1976a; Sullivan, 2009). ${ }^{4}$ Although there is an extensive literature about national banks and financial markets during the period, this paper is the first to estimate their effects on local growth.

The National Currency Act of 1863 and the National Banking Act of 1864 allowed the newly created Comptroller of the Currency to charter national banks, which could issue national bank notes backed by US treasury bills-in effect allowing these banks to issue and back US currency. State banks were slow to convert to national banks, and so in 1865 Congress passed a new act which established a $10 \%$ tax on state bank notes. Not surprisingly, over the next year almost all state banks converted to national banks or closed down (White, 1983). In the late 1880s as deposit banking became more important and states allowed banks to form without a special charter, the number of state banks increased rapidly, filling an apparent void left by the national banking system. Yet the national banks still held over $74 \%$ of all banking assets in $1900 .^{5}$ The commercial

\footnotetext{
${ }^{4}$ The national banking system played an important role in the early discussion of the importance of money, banking, and credit. For example, the new Review of Economics and Statistics published a four part series from 1924 to 1927 solely on national bank statistics starting with Young (1924). Similarly, the Journal of Political Economy published a four part series, a comment and a reply starting with Moulton (1918) on commercial banking and capital formation whose primary source of data was the national banks.

${ }^{5}$ Figure S. 1 in the separate online appendix shows the growth of state and national banks over the period. It is clear
} 
paper market also became increasingly important, partly as a response to the lack of large scale investment banking (Calomiris, 2000, pp. 48-49).

One goal of the National Banking Acts was to create a uniform bank note currency that would trade at par. To help ensure the stability of the new monetary and banking system, the acts imposed several restrictions on the new banks including a prohibition on taking mortgages as collateral and large minimum capital stock requirements to enter. The goal was to have the national banks be stable and well enough capitalized that their bank notes would trade at par. A national bank needed at least $\$ 50,000$ in capital stock to form, and faced larger limits in highly populated areas. ${ }^{6}$

The national banks were involved in many of the activities of modern banks, but were particularly important for their short term liquidity provision and the working capital they provided. Banking theory typically divides the services banks offer into four main categories: (1) providing liquidity and payments to ease the exchange of goods and services, (2) risk management and pooling savings, (3) monitoring investments, and (4) asset and maturity transformation. ${ }^{7}$ The national banks were involved in all four categories to some extent, much like the modern "universal bank," but were generally limited to making only short-term loans. Their main investment activities were providing liquidity directly by issuing bank notes, indirectly through providing working capital to producers and merchants, and moving funds through their role in the payments system. For exam-

that there were few state banks until the 1890s. See James (1978, pp. 29-39) and Barnett (1911, pp. 11-12, 32-33) for a discussion of the spread of state banks. After around 1890, many states had less stringent capital requirements than the National Banking Act (James, 1976b), which allowed state banks to open more easily.

${ }^{6}$ The limits increased by population size: banks needed $\$ 50,000$ in a town with no more than 6,000 inhabitants, at least $\$ 100,000$ in cities between 6,000 and 50,000, and at least $\$ 200,000$ in larger cities. The evidence does not suggest that the limits above $\$ 50,000$ were strictly enforced; banks could simply open in a nearby town if they did not want to open with a large amount of capital. Between 1870 and 1880, counties with cities with populations between four and six thousand gain somewhat more banks per capita than counties with towns over six thousand, but the difference is statistically insignificant, despite the doubling of required capital as population increased over six thousand. The capital size appears to have been reasonably easy to circumvent by opening in a nearby town. While it seems possible to use the change in capital requirements around 6,000 as an instrument to estimate the effect of banking, it does not have good explanatory power.

${ }^{7}$ See, for example, Freixas and Rochet $(2008$, p. 2). See also the review of the role of financial institutions in growth in Levine (2005, p. 869) for a similar taxonomy. 
ple, in 1876 their regulator, the Comptroller of the Currency, held that: "As banks are commercial institutions, created for commercial purposes, preference in discounts should always be given to paper based upon commercial transactions. Banks are not loan offices. It is no part of their business to furnish their customers with capital ..." (quoted in Bolles (1903, p. 121)). National banks were prohibited from taking real estate as collateral and the banking practice of the day pushed them to make only short-term self-liquidating loans. ${ }^{8}$ Further, around two thirds of the deposits of the banks in rural ares were time deposits (James, 1978, p. 69). Given the short duration of their loans, that means they did not offer substantial maturity transformation.

To analyze the effects of these banks, I have created a new data set at the bank level of all national banks in 1870, 1880, 1890, and 1900. The bank level data comes from the national bank accounts collected by the Comptroller of the Currency (who is still the official regulator of national banks), and reported to Congress each year. ${ }^{9}$ The accounts of each bank report the town or city in which it was located-which since branching was not allowed was its only place of business. I match these towns and cities with the place names from the Graphical Names Information System maintained by the US Board of Geographic Names, which gives gives the precise location of every bank.

The census collects a wide range of demographic and economic information every ten years and reports the aggregates for counties, which are sub-unit of states, almost always with their own local governments. In keeping with the importance of agriculture during the period, the census collected detailed information on farm production, yields, and farm size, as well as some information on manufacturing production. Haines and ICPSR (2010) collected and entered this information and

\footnotetext{
${ }^{8}$ This banking theory was known as the "real-bills" doctrine (James, 1978, p. 59-64). Banks certainly skirted its rules to some extent (Keehn and Smiley, 1977), in particular the self-liquidating requirement, by renewing some loans when they became due. Nonetheless, loan maturities were short: James $(1978$, p. 61) suggests that the average maturity was about 60 days although the country banks may have had longer maturities.

${ }^{9}$ Available in pdf from the St Louis Federal Reserve, http://fraser.stlouisfed.org/ publications/comp/, accessed 7 July 2010.
} 
I use the National Historical Graphical Information System (Minnesota Population Center, 2004) to match the the census data with counties and the location of banks. County boundaries shift occasionally, so to create a consistent panel I standardize on the 1890 county definitions.

Table 1 shows descriptive statistics for banking and the economic variables over counties and for each decade. Throughout the analysis, I exclude all counties that had an urban population of 50,000 or more in 1880 , which excludes counties with major cities. Since these counties are not constrained by the minimum capital stock requirement and the activities of banks in counties with large urban populations were different than banks in rural counties, it makes sense to exclude them from the analysis. The table shows statistics for both all rural counties, and separately for the rural counties in the "Union" states in the North-East, Atlantic, and Midwest. ${ }^{10}$ Combining farm and manufacturing production from the census, I create a measure of total production per capita. While it does not include services, and so does not directly measure aggregate output, services would have been a small portion of the economy at the time. I do not adjust for deflation or inflation in the table or the regressions, but instead allow for time effects throughout the analysis. There was significant deflation during the period, particularly around the Resumption Act of 1875, and so values in nominal dollars tend to understate growth.

The average county population grows substantially over the time period. Following a dip in nominal values during the 1870 s, so does manufacturing and farming production per capita, and in real terms both are growing quickly. ${ }^{11}$ The average number of banks increases over time as well, particularly during the 1880 s, when the banks per capita more than doubles. Moreover, banks tended to fill in gaps in geographic coverage - the average distance to a bank declines substantially

\footnotetext{
${ }^{10}$ The full list of states in the restricted sample is: Connecticut, Delaware, Illinois, Indiana, Iowa, Kansas, Kentucky, Maine, Maryland, Massachusetts, Michigan, Minnesota, Missouri, Nebraska, New Hampshire, New Jersey, New York, Ohio, Pennsylvania, Rhode Island, Vermont, West Virginia, and Wisconsin.

${ }^{11}$ Manufacturing production tends to be fairly concentrated even when I exclude counties with an urban population of more than 50,000 in 1880. So although total manufacturing production is more than half of aggregate production in some years, in an unweighted average over counties it represents less than half of total production since many counties have little manufacturing.
} 
from 1870 to 1890 . Table S.1 in the separate appendix gives additional statistics on the number and size of the national banks from 1870-1900.

\section{Bank entry in the presence of minimum capital constraints}

This section examines the entry decision of national banks. It begins by providing empirical evidence that the minimum capital stock requirement constrained entry. Motivated by that evidence, I introduce and estimate a simple model of entry in the face of the minimum capital constraint. The next section then shows how to use the implied discontinuity to estimate the causal effect of bank entry on county outcomes. While the modern banking literature discusses capitalization requirements a great deal, it typically refers to a minimum equity-to-assets ratio which would not necessarily have constrained entry, instead of a not a minimum dollar amount equity.

\subsection{Bank entry and evidence of constrained entry}

Figure 1 shows the histogram of capital stock in $\$ 1,000$ s in counties from 1870 to 1900 . There are many counties bunched at 0 (no entry) and 50 (minimum size entry). Since some banks enter with more than 50, the bunching at 0 and 50 suggests that the minimum was constraining. The last panel in figure 1 shows the capital stock distribution in 1902. As suggested by Sylla (1969), the best evidence that the minimum capital stock requirement was binding, even at the end of the period, is what happened when it was loosened. Congress reduced the minimum capital stock requirement from $\$ 50,000$ to $\$ 25,000$ in 1900 . Within two years hundreds of new banks entered at the minimum size, some banks at $\$ 50,000$ reduced their capital, and the number of unbanked counties fell substantially. Such changes show that the minimum capital stock constraint must have been binding, since banks were willing to enter counties at the new lower capital stock requirements that they had not been willing to enter before. The capital structure of banks mattered for entry. 
The top two panels of figure 2 show how total assets, and loans and discounts varied with the capital stock. Capital stock and total liabilities vary approximately linearly. By modern standards these banks were very well capitalized: capital stock was usually around one quarter of total assets. Capital stock also scales nearly linearly with loans (banks made other investments beyond loans, including issuing bank notes and holding bonds). This suggests that the amount of capital stock in a county is a good representation of the amount of banking activity in a county.

The bottom two panels of figure 2 also provide the first evidence that the constrained entry mattered for other outcomes. Both capital stock and capital stock per person vary approximately continuously with log production per person as long as there are banks in a county. There is a precipitous drop of more than $30 \%$ in production per person going from some banking to no banking. There is nothing special about the $\$ 50,000$ minimum except for its effect on entry, so surely at least some of these counties could have supported a smaller bank. Of course, some of the counties were in the Nevada desert, so simply comparing counties with banks to those without is problematic. I return to this difficult empirical problem in section 4.

\subsection{Optimal entry with a minimum capital requirement}

It is clear from figure 1 that the minimum capital stock constrained entry and so how banks were capitalized affected their decisions. In the supplemental appendix, I introduce a simple model of a profit maximizing bank deciding whether to enter a given county. In a Modigliani and Miller (1958) framework, a bank's financial structure is irrelevant and so the minimum capital stock requirement should not matter. The key friction that makes the capital structure and the presence of a local bank matter is that both local borrowers and depositors do not have access to the national market. The bank can therefore offer valuable services to depositors who value the returns offered by deposits

or their liquidity as in recent work by DeAngelo and Stulz (2014). The lack of financial access by 
locals means that the bank can pay a lower rate on deposits than for its equity, and so would like to rely entirely on deposits. The bank is limited in relying entirely on deposits by the minimum capital stock and by the depositors themselves who demand higher returns as the bank attempts to raise more deposits. The model builds on the idea of these banks as local monopolists (Sylla, 1969) by adding frictions in raising capital and so giving banks an optimal capital structure.

The model of profit maximizing banks suggests that when unconstrained by the minimum capital constraint, banks have an optimum capital stock in a given county. I model that optimum as a function of the county population $P_{c t}$ and local unobservable business conditions $\eta_{c}$ and local temporal shocks $\epsilon_{c t}$ :

$$
C_{c t}^{*}=\alpha \alpha_{t} P_{c t}^{\theta+1} \eta_{c} \epsilon_{c t} .
$$

The supplemental appendix shows how to get equation 1 as an exact representation of profit maximizing behavior given linear demand and supply curves, but the log linear form is a reasonable reduced form even without those assumptions.

When banks do face a minimum capital constraint, they must decide whether entry in any given county is still profitable. If a bank enters with too much capital, it becomes unprofitable, and so the minimum capital stock constrains entry. Since banks may be constrained, what a bank actually does and is observable $\left(C_{c t}\right)$ may be different from what a bank would like to do $\left(C_{c t}^{*}\right)$. Suppose demand for banking is very high. As long as $C_{c t}^{*}>50$, the bank is unconstrained and so $C_{c t}^{*}=C_{c t}$. As the demand for banking declines, so does $C_{c t}^{*}$. If $C_{c t}^{*}<50$, the bank must decide either to enter with 50 in capital stock, so that $C_{c t}=50$, or not enter at all, so that $C_{c t}=0$. At some transition capital, $C^{T}$, the bank is indifferent between opening or not. $C^{T}$ is the optimum capital in equation 1 in the county where $\pi(C=50)=0$. Having to open with a minimum capital introduces a discontinuity in capital stock and entry. Counties whose demand for banking means the optimal capital stock just above $C^{T}$ have a lot more banking than counties with an optimal capital stock 
just below $C^{T}$. In section 4, I use this discontinuous entry to estimate the causal effect of banking.

\subsection{Estimating optimal capital stock}

The evidence and model of profit maximizing banks suggests that the minimum capital constraint kept banks from entering some places. If there are no banks in a county, then $C_{c t}^{*}$ must be below $C^{T}$, the minimum threshold for entry. A county with a bank with 50 capital stock must have optimal capital between $C^{T}$ and 50 . Counties with larger banks have exactly their endogenous optimal capital. Each county may fall into all three categories over the full panel.

To estimate the relationship, I employ a maximum likelihood estimator (MLE) for the reduced form equation 1 which accounts for the constraints given by the minimum capital requirement. The MLE assumes that $\ln \epsilon_{c t} \sim N\left(0, \sigma_{\epsilon}^{2}\right)$ and $\ln \eta_{c} \sim N\left(0, \sigma_{\eta}^{2}\right)$ which puts positive weight on all possible $C_{c t}^{*}$ given the observed behavior for a given county. Maximizing the likelihood is made more difficult by the county level dependence of each time observation on $\eta_{c}$ which requires using numerical integration to get the log-likelihood for each county conditional only on the data. Appendix S.2 constructs the likelihood function and discusses estimation.

The results of estimating the entry model allowing for the discontinuity in actual entry are in table 2. Note that all specifications have extremely small standard errors. Column 1 shows the estimates for all counties, while column 2 shows the estimates using the capital stock in 1902. Columns 3 and 4 restrict the sample to rural counties in border or Union states. The last column restricts the population scale effect $(\theta)$ to zero. The estimates in the first column suggest there is a great deal of fixed heterogeneity across counties $\left(\sigma_{\eta}\right)$, and a much smaller individual county decade heterogeneity $\left(\sigma_{\epsilon}\right)$. The importance of the fixed component suggests that how good a place is for banking is largely fixed, and so entry depends particularly on whether a county has a sufficient population to sustain a bank of at least the minimum size, rather than on whether a county has 
an idiosyncratic shock. These results reflect the experience of the period of population growth accompanied by entry, with relatively few counties losing banking (although individual banks do exit). Banks were not willing to enter with $\$ 50,000$ in unless the population and business climate were enough to make their optimal capital $\$ 17,041$, which suggests that entry with the minimum capital was profitable even when banks were pushed forced to enter with more than double their optimal capital stock.

In 1900 Congress reduced the minimum capital to $\$ 25,000$ and hundreds of banks entered between 1900 and 1902. To use the change, I treat the entry behavior of banks in 1902 as what banks would have done in 1900 if they could enter with a minimum capital stock of $\$ 25,000$. This introduces a new threshold $C_{25}^{T}$ that only applies in 1900 . So if a bank enters with $\$ 25,000$ in 1902 in a county without a bank in 1900, the optimal capital stock in 1900 must have been more than the threshold for entering at $\$ 25,000\left(C_{25}^{T}\right)$, but less than the threshold for entering at $\$ 50,000\left(C^{T}\right)$. That clearly brings in a great deal of information since it separates counties that are very bad places for banking (they cannot even get a small bank) from counties that are only poor places for banking and so can support a small bank but not a larger one. With the estimates using the capital in 1902, the entry threshold increases to $\$ 22,772$, and banks were willing to enter at the new minimum of $\$ 25,000$ if their optimal capital was at least $\$ 13,275$.

\section{The causal effect of banking on production}

This section lays out a potential outcome framework for estimating the effects of national banks on production. It begins by discussing the identification problem when there is a constraint on entry. It then shows reduced form estimates for the effects of banks, before using the constraint directly. National banks were not the only sources of financial services in rural areas, although they were the largest. As with any attempt to identify the effects of adding financial services, the counterfactual 
is not financial autarchy: personal credit, trade credit, state banks, and traveling further to gain access to institutions not available locally all provided some access to financial services. Instead the goal of this paper is to measure the effects of putting a national bank close by with all of the services that it offers above what is already available. Until the late 1880 s the national banks were the only banks entering in any serious numbers (Barnett, 1911) and were by far the largest, and so for much of the period the effect of a national bank is close to the effect of gaining access to any bank. I examine how competition with state banks may have affected the results and show estimates for 1870-1890 separately in section 6.

\subsection{The empirical problem: estimation when entry is unconstrained}

First, consider the situation if banks could freely enter and so decide to open with the capital stock $C_{c t}^{*}$ in a given county $c$ at time $t$ that maximizes profits. Throughout I use a star $(*)$ to indicate that the variable is what would happen if banks could enter freely and without the minimum size constraints. Then we might try to estimate:

$$
Y_{c t}^{*}=\gamma_{c}+\gamma_{t}+\gamma_{e} C_{c t}^{*} / P_{c t}+U_{c t}^{*}
$$

where $Y_{c t}^{*}$ is the outcome of interest (typically log production per person), $P_{c t}$ is county population, and $\gamma_{c}$ and $\gamma_{t}$ are county and time specific effects.

The parameter $\gamma_{e}$, where the e emphasizes endogeneity, is not likely to capture a causal effect in general. The main identification problem is that $C_{c t}^{*}$ is chosen by banks who decide where to enter and at what size based on their own profitability. If we could take away banks' power to choose where to go and randomly assign them to enter counties as recent studies of microfinance do (Banerjee et al., 2013), then it would be possible to get a causal estimate. The central empirical difficulty of how finance affects development is how to estimate the effect of banking on economic 
activity so that it has a causal interpretation when placement is generally endogenous. ${ }^{12}$

The second major difficulty in estimating the effect of finance or banking is that the effects may vary over time. Credit, by definition, allows some people or firms to bring forward investment or consumption, while others to delay it. Relieving credit constraints or introducing a new savings options are likely to have effects that vary over time, possibly dramatically. For example, Fulford (2013) shows that the effect of financial access in the long term can be the opposite of what holds in the short term. Usefully, the problem is reasonably easy to deal with: Fulford (2013) shows that including past values of the banking variable deals with the problem by allowing the effects to vary over time. Allowing time varying effects means that a bank can have an effect on entry that differs from its effect a decade or more later. Not allowing dynamic effects forces these effects to be the same which is both theoretically and empirically questionable.

\subsection{Estimation when entry is constrained}

Banks could not enter freely during the period; they had to open with a minimum capital stock of $\$ 50,000$. In some counties, banks that would have entered with a profit maximizing capital less than $\$ 50,000$ instead were forced to enter with the minimum capital. Other counties were denied banking that they would have had since banks did not find it profitable to enter with such a large capital stock. The minimum capital requirement thus causes the capital stock to jump discontinuously from $\$ 0$ to 50,000 , even though we might expect that the underlying economic activity which attracts banks behaves continuously. Small changes in the underlying fundamentals that attract banks thus cause big changes in the amount of banking. To make the exposition easier to read, capital stock is measured in $\$ 1,000$ s throughout.

There are many counties that could have supported a smaller bank but did not have a national

\footnotetext{
${ }^{12}$ See Levine (2005) and King and Levine (1993) for some attempts to deal with this problem comparing countries. Rajan and Zingales (1998) examine industries which are more likely to benefit from finance. Burgess and Pande (2005) use social banking rules in India as an instrument for which districts received more banks.
} 
bank because of the minimum size requirement. That is empirically evident by the entry of many banks at the smaller size after the rules were loosened in 1902 (see figure 1). When entry is constrained, there is a distinction between what banks want to do $\left(C_{c t}^{*}\right)$ and what they actually do $\left(C_{c t}\right)$. Banks cannot open at $C_{c t}^{*}$ unless $C_{c t}^{*} \geq 50$. Instead, banks must either open with 50 in capital stock or not at all. For constrained counties the actual capital is either $C_{c t}=0$ or $C_{c t}=50$. The observed capital in a county is therefore a discontinuous function of what banks actually want to do: the observed capital $C_{c t}=50 D\left(C_{c t}^{*} \geq C^{T}\right)$ where $C^{T}$ is the threshold at which entry becomes profitable and $D(\cdot)$ is a dummy or indicator variable. The minimum size requirement means that some places have too much banking, others too little. A useful notation for the amount of "Excess Capital" is $E C_{c t}=C_{c t}-C_{c t}^{*}$. It is positive when a bank decides to enter, but negative for counties that are denied banking because of the rule, and jumps by 50 as $C_{c t}^{*}$ passes $C^{T} . E C_{c t}$ measures how much more or less banking capital stock a county has because of the minimum size requirement.

The top panels of figure 3 illustrate how the actual capital stock is a discontinuous function of the optimal capital stock. For very low optimal capital stock, profits are negative and so no entry occurs, and the observed capital stock is zero. When optimal capital stock is greater than $C^{T}$, entry occurs, and the actual capital stock jumps to 50. Excess capital is negative below entry, then jumps to positive as a bank enters with more than its optimal capital stock.

For the constrained counties affected by the minimum capital requirement there are two different relationships of outcomes with banking. One is the endogenous relationship captured by equation 2. But that is no longer the full story and estimating equation 2 on the constrained counties would not even correctly capture the non-causal correlation $\gamma_{e}$ since the minimum size requirement is pushing banks away from their optimal capital. The minimum size regulation has its own effect on the outcome given by:

$$
Y_{c t}-Y_{c t}^{*}=\gamma E C_{c t} / P_{c t}+U_{c t}
$$


where $Y_{c t}$ is the outcome with the rule and $Y_{c t}^{*}$ is the outcome without the rule if banks could enter freely. If $\gamma$ is positive, then areas with a constrained bank have more output per capita than they would without the minimum size requirement, while areas without a bank are denied banking services they might otherwise have had and so have less output. $\gamma$ measures the effect of the minimum size requirement. It is a causal effect in the sense that it measures what happens when counties that otherwise would have different amounts of banking are forced to have more or less because of a regulation.

If we could observe what banks actually want to do, then combining equations 2 and 3:

$$
Y_{c t}=\gamma_{c}+\gamma_{t}+\gamma_{e} C_{c t}^{*} / P_{c t}+\gamma E C_{c t} / P_{c t}+e_{c t}
$$

estimates both the endogenous effect $\gamma_{e}$ and the effect of the regulation $\gamma\left(\right.$ where $\left.e_{c t}=U_{c t}+U_{c t}^{*}\right)$. The standard sharp regression discontinuity result is that $\gamma$ is identified holds as long as the density of $e$ conditional on $C^{*}$ is continuous (see, for example, Imbens and Lemieux (2008) or Hahn, Todd, and Klaauw (2001)). A regression discontinuity does not require $C^{*}$ to be uncorrelated with $e$ since identification of the causal effect $\gamma$ is coming from the jump in $E C$ which is a function of $C^{*}$. Sharp regression discontinuity designs have an "unavoidable need for extrapolation" (Imbens and Lemieux, 2008, p. 618) away from the threshold, although with copious data it may be possible to minimize the extrapolation by estimating close to the threshold. Note that the panel dimension of the data is not used at all in a standard regression discontinuity (Lee and Lemieux, 2010, pp. 337-338). ${ }^{13}$

\footnotetext{
${ }^{13}$ To see why the discontinuity is important, consider an alternate (bad) rule: banks must open with twice their optimal capital stock. So $E C_{c t}=C_{c t}-C_{c t}^{*}=2 C_{c t}^{*}-C_{c t}^{*}=C_{c t}^{*}$. The underlying estimating equation collapses into: $Y_{c t}=\gamma_{c}+\gamma_{t}+\left(\gamma_{e}+\gamma\right) C_{c t}^{*} / P_{c t}+e_{c t}$. The causal effect of the rule is still $\gamma$, but there is no way to separately identify it from the endogenous effect $\gamma_{e}$ since both are continuous.
} 


\subsection{Reduced form estimates}

Reduced form estimates help understand the magnitude of the endogenous effect and the effect of the constraint and so are a useful place to start. In the all of the estimates, as well as in figure 2, I normalize capital stock per person so that it is in units of adding $\$ 50,000$ to the average population of the marginal county. To calculate that population, I take the average population from 1870-1900 of all counties that either have a single bank with $\$ 50,000$ in capital stock or will get one during the period and have a population greater than 1000 giving a population of 14,755 . This normalization affects the size of the estimates but not their significance and the population is not far off from the average rural population in 1880 in table 1 . Normalizing this way means that all of the estimates can be compared directly to the effect of adding a minimum size bank to the marginal county.

To understand the endogenous effect of unconstrained entry, I first estimate equation 2 using only counties that have a bank. Panel A in table 3 shows the results. In is simplest form without county fixed effects, this estimate is equivalent to finding the slope of the bottom right panel of figure 2. Conditional on having a bank, gaining the equivalent of a minimum sized bank for the marginal population is associated with higher output per person of about $6 \%$ across all counties. Putting in fixed effects or taking differences in the next two columns removes much of this effect, as one would expect if banks are attracted to more productive areas, giving an estimate of between 2 and $4 \%$ more production per person.

Panel B includes the counties without a bank and allows the effect of additional capital to be quadratic. While the minimum capital stock implies a particular form of discontinuous nonlinearity, it is useful to show estimates without that structure. Panel B shows that additional capital stock is less and less valuable: the effect of adding a 50 bank around the entry threshold for capital is nearly $15 \%$, while for a county which has 200 in national bank capital, adding 50 makes almost no difference. 
To consider the effect of entry, I next compare counties that have a bank that opened at the minimum size to counties that do not have a bank. Since counties that do not have a bank are also likely to be counties that are less attractive in many ways, such estimates are mostly useful as a comparison for later estimates that account for endogeneity. Panel $\mathrm{C}$ in table 3 compares the capital stock per capita of counties without a bank and with a 50 capital bank, while panel D simply includes an indicator for whether the county had a bank. Without fixed effects or first differences, it is clear that counties with banks are much more productive; production per person is $22 \%$ higher using capital stock per person or $37 \%$ higher using the indicator for the presence of a bank. As one might expect if endogeneity is important, including fixed effects or first differences substantially reduces these estimates to between 12 and $17 \%$.

The difference between panel A and panels $\mathrm{C}$ and D gives one approximation of the causal effect of entry. Panel A suggests the endogenous effect of gaining more capital stock per person $\left(\gamma_{e}\right)$ in equation 4 is around 2.5 and $4 \%$. Since the estimates with fixed effects in panels $\mathrm{C}$ and $\mathrm{D}$ are approximately the combined endogenous effect and the effect of entry at the minimum size $\gamma+\gamma_{e}$ in equation 4 , the effect of entry at the minimum size in an unbanked county is likely to be around 8 to $14.5 \%$.

A different approach to estimating the effect of bank entry is to construct comparison groups by finding counties where one might believe that the $C_{c t}^{*}$ are very similar between two groups but some counties had banks while others did not. The first comparison grouping makes use of the geographical dimension of the data. Neighboring counties might be very similar and a bank may enter one of them based only on small differences in expected profits. Then counties that gain a bank have similar optimal capital to their neighbors. The problem with this approach is that there is no reason to suppose that the effect of a bank stops at a county border, although it may be attenuated the further from the bank a person lives. The comparison counties may be better off because they 
are next to a county where a bank entered and so the effect of banking may be underestimated. I explicitly consider distance at the end of section 6 and in the supplemental appendix.

Panel E in table 3 shows several different approaches to defining the neighboring counties. Since whether a county is next to a county with a 50 capital stock bank is not fixed, all of the estimates use first differences and so compare the change in log production per capita in counties that get a bank with their neighbors. The first column includes all neighbors of a county with a 50 bank, the second limits the analysis only to neighbors that had a 50 bank or no bank, and the third includes neighbors as long as they have less than 200 capital stock. The results suggest that counties that get a 50 bank grow between 6 and $8.5 \%$ faster than their neighbors.

The second comparison group makes use of the panel dimension of the data by comparing counties that will get or had a bank with 50 capital stock to counties that have a bank now. A county that had a bank but lost it or a county that will get a bank in the next period may have a similar underlying attractiveness to banks. The idea is that the growth from 1870 to 1880 for a county that has a 50 bank in 1870 is a good comparison to the growth from 1870 to 1880 for a county that gets a bank during the decade. The last panel in table 3 shows these estimates. Depending on whether the sample includes all counties that gain or lose a 50 bank (which includes some counties that have more than one bank), or only counties that one or zero banks, the estimates are between 7.8 and $10.7 \%$.

\subsection{Estimating using the discontinuity directly}

The behavior of banks during the period means there is an underlying discontinuity in where banks enter and the model of profit maximization with a minimum size constraint gives that discontinuity an explicit structure. Reduced form estimates that do not take that structure into account do not correctly capture the effects of banking since they are combining the endogenous relationship of 
banking with the effect caused by the minimum size constraint.

The key to estimating the effect of bank entry is that while $C_{c t}^{*}$ is not observable, using the estimation in section 3.3 provides a conditional density of $C_{c t}^{*}$ for each county and time. First, the optimal capital stock within a county must be consistent with the observed entry of banks into that county at every decade. Second, the distribution of optimal capital stock depends on where banks have entered and at what population in all counties over the entire sample. The optimal capital stock estimation gives a distribution that is unique to each county and decade of the many things unobservable to the econometrician that make a county a more or less desirable place to do banking. For example, consider two counties that do not get banks between 1870 and 1900, but one of which gets a bank with $\$ 25,000$ in capital stock between 1900 and 1902 when Congress reduces the minimum. While we still do not know exactly what would have happened without the constraint, the entry by 1902 in one county suggests the distribution of optimal capital in 1900 must have been substantially higher than in the county where no bank found it profitable to enter even at the reduced minimum capital. In section S.3 of the supplemental appendix, I give further examples and show the estimated distributions from several counties with varying entry experiences.

Non-parametric estimates. Using the distributions from the optimal capital stock estimation from the previous section necessarily implies some parametric assumptions. It is nonetheless useful to begin examining the effects of banking without imposing any additional structure on the problem. I begin by drawing many potential optimal capital stocks for each county in each decade from its own conditional distribution. Counties with higher density close to the dividing line are more likely to have draws close to the threshold. The only information in the conditional distributions comes from what was used to form the optimal capital stock estimation: the actual entry and size of banks and the population of the county over the panel.

Figure 3 shows how these draws relate to the county characteristics. Each dot represents the 
average of all of the counties that had an optimal capital stock draw within a bin $\$ 1,000$ wide. The top two panels show how the observed capital stock and excess capital stock vary with the optimal capital stock. When optimal capital is below the threshold, banks do not enter and actual capital is zero. When optimal capital is above the threshold, banks enter at the minimum capital of 50. ${ }^{14}$ By definition, excess capital is the difference between what a county would have if entry were unconstrained and what it actually gets. Excess capital is therefore negative below the entry threshold, and then positive and declining above the threshold. The larger dots above 50 are the average over a 5 capital wide bin of the counties with banks with actual capital greater than 50 . The optimal capital stock estimation treats these banks as unconstrained so their optimal capital stock is their observed capital stock and so their excess capital stock is zero.

If we were to take these draws as actual data, a standard regression discontinuity approach would examine how predetermined county characteristics vary with the assignment variable to understand whether the assumption that the density of the unobservables around the threshold is continuous. Figure 3 shows several such approaches. County population does not jump around the threshold of entry. Since population is in the optimal capital estimation the estimates of optimal capital already condition on it. Nonetheless, it is good to see that it does not jump when crossing the entry threshold. Next, I examine log county area which is certainly predetermined (in the appendix, I also show a similar graph for the distance to St. Louis, a major trading city). The optimal capital stock estimation does not condition on area or location. The figure shows that area varies approximately continuously with optimal capital stock and does not jump discontinuously at the entry point.

Similarly, there is no break around the dividing line for entry in log production per capita in

\footnotetext{
${ }^{14}$ When optimal capital gets close to 50 , there is some variance because the optimal capital estimation allows for having multiple constrained banks in a county each acting as a monopolist in its own area. It is possible for a two bank county with actual capital of 100 to have an optimal capital only barely sufficient for entry for each. There are relatively few such counties and excluding them does not affect the results but I show them for completeness.
} 
1860. There were no national banks in 1860 so they could not have affected output then. Along baseline log production per person, counties that are more likely to be close to the line but just did not get a bank are very similar to counties that are likely to be close to the line but got a bank.

Finally, I examine the main outcome of interest: log production per person. I first remove year effects so that price changes do not affect the results. As optimal capital stock increases, log production per person increases with a discontinuous jump at entry. Taking the difference between the means on either side within $\$ 2,000$ of the entry line, the effect of a bank entering at the minimum size is $12.7 \%$. The comparison between the production in 1860 and 1870-1900 illustrates the discontinuity of entry and its large impact: counties with banks did produce substantially more during the period than otherwise very similar counties, even though they were very similar beforehand.

Estimation using the conditional mean. My preferred approach uses only the conditional mean of optimal capital stock for each county and decade and so is less sensitive to the relative densities at the dividing line. The approach is very simple: estimate equation 4 with the mean optimal capital stock from the density for each county-decade $\left(\bar{C}_{c t}^{*}\right)$ replacing the actual but unobserved optimal capital stock $\left(C_{c t}^{*}\right)$.

Under what conditions will estimating equation 4 with the conditional means estimate $\gamma$ ? The first requirement is that equation 4 captures the true structure of the problem including that the relationship of capital stock per person and output per person is linear even away from the the entry point. Then if we observed $C_{c t}^{*}$ estimating equation 4 using ordinary least squares with all of the data would be the best linear unbiased estimator of $\gamma$ (Lee and Lemieux, 2010, p. 286). The second requirement is that the conditional mean is unbiased. Define $C_{c t}^{*}=\bar{C}_{c t}^{*}+u_{c t}$. If $E\left[u_{c t} \mid \bar{C}_{c t}^{*}\right]=0$ so that $\bar{C}_{c t}^{*}$ is an unbiased predictor of $C_{c t}^{*}$, then replacing $C_{c t}^{*}$ with $\bar{C}_{c t}^{*}$ in equation 4, OLS still recovers $\gamma$. This result comes from the optimal prediction error model in Hyslop and Imbens (2001), but is just a variation on the result that replacing individual observations with group 
aggregates does not create bias (see, for example, Deaton (1997, pp. 100-101)). The key point is that, unlike with classical measurement error where the error is assumed to be independent of the true value, here the error is independent of the observed value and correlated with the true value.

Under these two assumptions replacing the actual optimal capital stock with its conditional mean still estimates $\gamma$ without bias. This approach assumes that the functional form in equation 4 holds. It does not, however, require as much from the optimal capital stock estimation except that it deliver unbiased conditional means that vary by county and decade. It is crucial that the conditional means vary and this is where the panel becomes important. In a single cross-section the conditional means of all counties below entry would be the same (except for the effect of population which is removed by dividing by population in equation 4). The conditional mean is not helpful since it is just a constant. With the panel, the conditional means of different counties vary. The conditional means will vary much less than the true underlying $C_{c t}^{*}$, and so the standard errors will be much larger than if $C_{c t}^{*}$ were observable.

One potential check that $\bar{C}_{c t}^{*}$ is indeed a good predictor is to use additional information in the optimal capital estimation to form the conditional densities. In 1900 capital requirements for national banks were halved to $\$ 25,000$. Many new banks decided to enter in the next several years at the lower capital requirements, and some existing banks reduced their capital as shown in figure 1. Using the extra information from 1902 provides a useful test for whether the distributional assumptions for optimal capital stock are driving results. More information about the underlying distribution should not affect the results if the underlying distributional assumptions are correct since it should not change whether $E\left[u_{c t} \mid \bar{C}_{c t}^{*}\right]=0$. In practice, since the extra information should make the estimation more precise, I show results using 1902 and then examine whether not using the information affects the estimates.

Parametric estimates using the conditional mean. Table 4 shows the results from using the 
county conditional mean. As in the reduced form estimates in table 3, I normalize excess capital stock and optimal capital stock so they are in units of adding a bank of the minimum size to the marginal county population. The main estimates only use counties that have at least one decade in which the conditional mean is within 15 of the transition capital stock for entry $C^{T}$. Restricting the window keeps the estimates from being driven by counties that will never get a bank or have a great deal of capital stock already, and so relies less on the linear functional form of equation 4 . I consider both wider and smaller windows in section 6 . While the actual, but unobserved, optimal capital stock may be close to the transition capital $C^{T}$, the conditional mean is not generally very close to the transition since relatively little information is used by the optimal capital estimation.

The extra banking that the minimum capital stock brings increases production per person by $10.08 \%$. Including a one period lag suggests that there may be continuing growth effects rather than just a one off level effect: allowing for dynamic effects leaves the initial impact similar at 9.9\% and the second decade increases by $9.3 \%$. There is no evidence of a declining effect of bank entry. Instead, getting a bank appears to have a compounding growth effect.

Not using the information from 1902 barely changes the estimates. When using only the entry behavior from 1870 to 1900 to form the conditional mean the effect of the minimum capital stock requirement is $11.1 \%$. All of the estimates include time effects, or are in first differences, which should sweep out overall price changes over time. Since four time periods is a short panel, first differencing allows me to relax the relatively strong assumptions necessary to allow fixed effects in a short panel. First differencing comes at at an efficiency cost, however. The first difference estimates suggest a lower impact of the minimum capital stock requirement of $5.9 \%$.

The impact of optimal capital stock per capita is much smaller than the effect of the extra capital caused by the minimum capital stock requirement. The coefficient on optimal capital per person is about $3.4 \%$, very close to to the estimates in panel A of table 3 for the unconstrained 
banks. The effect of endogenous capital stock seems to be about the same above and below entry.

The effect of gaining a minimum size bank is substantially larger than the endogenous effect. We might expect that standard estimates that do not take into account endogeneity will overestimate the effects of banks since banks choose the most profitable places to enter. However, the estimated effect of gaining a minimum size bank contains two separate changes: gaining access to the services offered by a national bank, and gaining the excess capital caused by the minimum capital constraint. The pure entry effect cannot be separately identified from the extra capital caused by the minimum capital since they both occur at the same time. Since the endogenous effect is smaller, this suggests that the pure entry effect is a large. Having some access to a national bank seems to be very important.

\section{Decomposing the increase in production per person}

To examine how banking affects the components of total productivity, table 5 shows the conditional mean estimates for manufacturing value per capita, farm production value per capita, the share of manufacturing in total output, the percent of improved farm land, and farm yield. For a county with the marginal population, gaining $\$ 50,000$ in capital increased manufacturing production by a statistically insignificant $5.8 \%$. The increase in total production seems to be particularly driven by increases in farm production value per capita, which increased by $13.2 \%$.

Gaining a bank decreased the percent of manufacturing in the total production, as shown in the middle columns of table 5. A negative result is particularly striking because national banks could not lend on mortgages, and so the only direct way to promote agriculture was by providing working capital to farmers and merchants and helping commerce in general. These results, of course, hold only for the marginal rural county; national banks may have promoted industrialization in the cities, while facilitating agriculture in rural areas. 
Banks seem to have promoted agriculture largely on the extensive margin, rather than on the intensive margin. Table 5 examines how banking affected the fraction of improved farmland in a county and the yield (in dollars of production per acre). Improved farmland is land that has been cleared and is being tilled or is lying fallow, including orchards and permanent pastures, and so represents land that is actively used for agriculture. For all rural counties, there is no effect of excess capital stock on the yield in the regressions in levels. The land under cultivation, however, increased. Including lagged effects suggests that banks may have only a short-term effect on the amount of farmland compared to unbanked counties.

\section{Robustness}

To check the robustness of the results, I restrict the sample in several ways and examine the effect of including the information from 1902 and other changes in the conditional density in optimal capital. Table 6 shows the marginal effect and its p-value in brackets for all of the dependent variables for different changes in the sample and the optimal capital estimation. The first two columns collect the results from tables 4 and 5. The columns that show two lags sum the coefficient on the excess capital stock and its decade lag together and test their joint significance.

Not including 1902. One concern about the estimates is that the functional form and counties far from getting a bank are driving the results. Using the additional information about banking in 1902 after the minimum capital requirements went into effect gives a great deal of information about the distribution of optimal capital for counties with low populations and no banks. Not using the extra information then places greater emphasis on the functional form, and so helps understand how much the functional form is responsible for the results. Using the capital stock in 1902 also requires assuming that the banking situation in 1902 is identical to 1900 except for the variation in capital requirements, and that banks have had a chance to fully adjust by 1902 . The results not 
using 1902 are shown in the third and fourth columns of table 6 .

The estimates are largely unchanged, which is particularly striking since the sample of included counties is much larger for the estimates using all rural counties but not using 1902. Without the 1902 information counties without a bank in 1900 — many of the Western and Southern countiescould be anywhere below $C^{T}$. With the extra information those that still do not have a $\$ 25,000$ bank in 1902 are pushed very far from the line (now they must also be below $C_{25}^{T}$ ), and so are excluded by not being within $\$ 15,000$ of the entry point. That including so many additional counties, but in a way that accounts for the relative paucity of information about them, does not change the results suggests that the estimation approach is quite robust.

Excluding the South. While most of the analysis includes all rural counties, it is possible that banking in the sparsely populated West and poorly banked South had a different effects than in the North and Midwest. In addition, the inclusion of so many sparsely populated and poorly banked counties places additional weight on the functional form assumptions. It is not necessarily a problem that the rest of the country had few banks; although counties in the West did not get many banks, they also had very low populations, and so should have had few banks. Similarly, the regressions interpret the few banks in the South as meaning that the South was not a good place for banking. So restricting the sample also examines whether the estimation is driven by including areas with few banks. The "Union Rural" columns in table 6 restrict the sample to rural counties in Northern and Midwestern states, since these counties are the most comparable. Excluding the South and West does not change the results much. Not using the information from the change between 1900 and 1902 again leaves the results largely unchanged.

Other variations. In the online supplemental appendix, I further examine the robustness of the results by changing the sample of included counties in several ways and altering the functional form. First, I restrict the sample to remove the relatively few counties that have banks with $\$ 50,000$ 
and banks with more capital. Second, I restrict the sample to only include counties in which the mean optimal capital is within $\$ 10,000$ of the entry threshold rather than $\$ 15,000$. Third, I extend the sample to include all counties that are constrained during the period and so have either a bank at the minimum or no bank at all. There are many counties with low population which should have very little banking and including them puts a great deal of weight on the functional form. Changing the sample does not affect the estimates much. Finally, I restrict the population scale effect $(\theta)$ in the optimal capital stock estimation equation 1 to be exactly zero, and re-estimate the effects of banking. The effects of banking are slightly larger with the more restrictive functional form.

State banks. The estimated effect is for a national bank of the minimum size entering a rural county that does not have a national bank. It identifies the effect of providing the services of a national bank on top of the already existing financial services. This effect is not necessarily the effect of any access to banking, however, because other financial institutions existed at the time, including banks with state charters. It took until the 1880 s for many states to set up laws that allowed for the general incorporation of state banks without a special provision (James, 1978, pp. 233-4) after state banks were largely taxed out of existence with the National Banking Acts. Texas prohibited state banks entirely until after 1905 (James, 1978, p. 42). Until the late 1880s there were too few state banks to have much of an effect on estimation. Yet after 1890, state banks entered in sufficient numbers to provide real competition with the national banks, especially because they often had lower capital stock requirements and so could enter places un-profitable for national banks. ${ }^{15}$

The last columns in table 4 examine how the new competition with the state banks change the estimates. First, I estimate the effect of national banks only between 1870 and 1890 when state banks would not have had much of an impact. In 1870-1890, a national bank had a larger effect on

\footnotetext{
${ }^{15}$ Figure 1 in the separate appendix shows the comparative entry of state and national banks. It is clear that there were very few state banks until the late 1880 s but after that they grew quickly.
} 
production than on average across the period: $14.5 \%$ compared to around $10 \%$ with fixed effects and $6 \%$ in differences estimated across the entire period. It seems that the added competition from state banks did diminish the effect from national banks.

State bank minimum capital requirements were not uniform and so in some states the state banks would have provided more competition than others. In the last two columns of table 4, I show the effect of interacting the state bank capital stock minimum in 1895 with the excess capital measure in each decade. ${ }^{16}$ The reason for the decade interactions is that state bank minimums in 1895 would have only been an issue during the late 1880s and 1890s and so should not have an effect on the estimate of the effect of a national bank before that. In 1870 and 1880, the minimum state capital stock in 1895 has a zero or even positive effect. For the 1890s, however, higher state bank minimums lower the effect of national banks by a large and statistically significant amount. This suggests that rather than providing effective competition, areas with low state bank minimums had low minimums exactly because they were in generally unattractive places for banking. The low minimums were necessary to get any banking. The interaction effect is also consistent with the distance analysis I describe next. A bank (whether state or national) coming into an area where there are few banks close by should have a larger effect. As national banks spread out, and state banks joined them starting in the late 1880s, the effect of any bank should have diminished because it was improving financial access less.

Distance. Using geography to identify the effects of banking assumes that distance somehow matters. If someone in a county far from a bank can get a loan just as easily, then the presence of a local bank should make little difference. The spread of banks that accompanied the spread of population shows that local banking is important-otherwise all banking could be done at lower

\footnotetext{
${ }^{16}$ Using the state minimums is not straightforward, however. The state minimums changed over time and the earliest broad evidence appears to be from the Comptroller of the Currency in 1895 (see also Barnett (1911)). Even in 1895, many states did not have "free banking" and so did not have explicit minimums. Of the states that did have explicit minimums, there is fairly wide variation ranging from 0 in South Carolina, $\$ 25,000$ in Ohio and Georgia, to $\$ 100,000$ in Louisiana.
} 
cost in one location. But in identifying a single effect of extra capital, the estimate ignores that some counties are much closer to other sources of banking than other counties. In the supplemental appendix, I construct a measure of the distance to banking based on the mean distance to the nearest bank by area of each county. The interaction of distance with the excess capital suggests that banks have larger effects in counties where other banks are further away.

\section{Conclusion}

Although there has been much work on financial development, it is often difficult to identify the effects of financial institutions. By focusing on a banking regime in which there were important limits on banks, this paper helps clarify the importance of banking and sheds some light on how banking affects growth. The tightly constrained national banks were an important source of growth: for the marginal county close to the line between getting a bank and not the presence of a national bank increased production per capita by $10 \%$. The services that national banks could offer were clearly very important. National banks seem to have promoted both farming and manufacturing, but in the marginal rural counties tilted the production mix to agriculture. These banks seem to have promoted a move towards geographic comparative advantage, although the nature of the discontinuity means that the estimates only apply to rural counties.

Financial institutions may also cause reallocation of activity to some areas and away from others, just as transportation does (Donaldson, Forthcoming). Capturing such effects requires a full structural model of the economy allowing geographic and sectoral reallocation, and so requires far stronger assumptions than for a well-identified local average treatment effect. Yet the rapidly expanding variety and size of these institutions makes understanding the broader role of financial institutions in the economy and their importance for growth even more important.

The GDP per capita of the United States in 1870 would have put it someplace between India 
and China today (Maddison, 1995, p. 196), and the United States then shared many characteristics with developing countries today. In particular, the transportation infrastructure was poor relative to the present which made moving funds around difficult and getting goods to market costly which is still true in many developing countries today (World Bank, 2009). The rapid expansion of mobile phone banking (Mbiti and Weil, 2011) illustrates the large unmet demand in developing countries for basic banking and payment networks.

The national banks played a critical role in the payments system, giving people access to funds where and when they need it, not least by issuing currency directly. The mail-order catalog-the Sears Catalog is the best known-grew explosively during the period (Nystrom, 1915, pp. 235254). Just as the ability to transfer funds online has allowed new ways to buy goods today, the ability to transfer funds then promoted new forms of commerce. Because the modern financial system is so developed and the advent of telecommunications and information technology has made the payments system so efficient in developed countries, it is easy to forget that one of the primary roles of banking historically was to facilitate commerce by connecting distant places financially and providing exchange.

National banks both issued loans-typically of short duration and often to fund goods in transit-and national bank notes which as currency facilitated the exchange of goods. Since national banks were generally not making long-term loans to expand businesses or farms directly, and could not take mortgages as collateral, these banks' primary investment role was to provide working capital to producers and merchants, rather than provided the fixed capital to create new enterprises. That they mattered for growth suggests that these services are crucial in a growing and poorly connected economy. Facilitating a payments system, providing working capital, and funding goods in transit are key functions of banks during periods of growth and development. 


\section{References}

Admati, Anat and Martin Hellwig. 2013. The Bankers' New Clothes: What's Wrong with Banking and What to Do About It. Princeton, N.J.: Princeton.

Aghion, Philippe and Patrick Bolton. 1997. "A Theory of Trickle-Down Growth and Development." The Review of Economic Studies 64 (2):151-172.

Amiti, Mary and David E. Weinstein. 2009. "Exports and Financial Shocks." NBER Working Paper No W15556.

Banerjee, Abhijit, Esther Duflo, Rachel Glennerster, and Cynthia G. Kinnan. 2013. “The Miracle of Microfinance? Evidence from a Randomized Evaluation." Working Paper 18950, National Bureau of Economic Research. URL http: / / www . nber.org/papers/w18950.

Banerjee, Abhijit V. and Andrew F. Newman. 1993. "Occupational Choice and the Process of Development.” Journal of Political Economy 101 (2):274-298.

Barnett, George E. 1911. State Banks and Trust Companies since the Passage of the National Bank Act. Washington: Goverment Printing Office.

Benfratello, Luigi, Fabio Schiantarelli, and Alessandro Sembenelli. 2008. "Banks and innovation: Microeconometric evidence on Italian firms.” Journal of Financial Economics 90 (2):197 - 217.

Binder, John J. and David T. Brown. 1991. "Bank Rates of Return and Entry Restrictions, 18691914." The Journal of Economic History 51 (1):47-66.

Bolles, Albert S. 1903. Practical Banking. Indianapolis: Levey Bro's \& CO., eleventh edition ed.

Burgess, Robin and Rohini Pande. 2005. "Do Rural Banks Matter? Evidence from the Indian Social Banking Experiment.” The American Economic Review 95 (3):780-795.

Calomiris, Charles W. 2000. US. Bank Deregulation in Historical Perspective. Cambridge: Cambridge University Press.

Cetorelli, Nicloa and Philip E. Strahan. 2006. "Finance as a Barrier to Entry: Bank Competition and Industry Structure in Local U.S. Markets.” The Journal of Finance 61 (1):437-461.

Davis, Lance E. 1965. "The Investment Market, 1870-1914: The Evolution of a National Market." The Journal of Economic History 25 (3):355-399.

de Mel, Suresh, David McKenzie, and Christopher Woodruff. 2008. "Returns to Capital in Microenterprises: Evidence from a Field Experiment." The Quarterly Journal of Economics 123 (4):1329-1372. 
DeAngelo, Harry and Rene M. Stulz. 2014. "Liquid-Claim Production, Risk Management, and Bank Capital Structure: Why High Leverage is Optimal for Banks." Working Paper 2013-8, Charles A. Dice Center. URL http: / / ssrn. com/abstract $=2254998$.

Deaton, Angus. 1997. The Analysis of Household Surveys: A Microeconometric Approach to Development Policy. Baltimore: Johns Hopkins University Press.

Donaldson, Dave. Forthcoming. "Railroads of the Raj: Estimating the Impact of Transportation Infrastructure." American Economic Review (NBER Working Paper 16487).

Freixas, Xavier and Jean-Charles Rochet. 2008. Microeconomics of banking. Cambridge, MA: The MIT Press, 2nd ed.

Fulford, Scott. 2011. "If financial development matters, then how? National banks in the United States 1870-1900.” Boston College Working Paper 753 (available: http://fmwww.bc.edu/ecp/wp753.pdf).

- 2013. "The effects of financial development in the short and long run: Theory and evidence from India." Journal of Development Economics 104:56-72.

Galor, Oded and Omer Moav. 2004. "From Physical to Human Capital Accumulation: Inequality and the Process of Development." The Review of Economic Studies 71 (4):1001-1026.

Galor, Oded and Joseph Zeira. 1993. "Income Distribution and Macroeconomics." Review of Economic Studies 60:35-52.

Greenwood, Jeremy and Boyan Jovanovic. 1990. "Financial Development, Growth, and the Distribution of Income.” The Journal of Political Economy 98 (5):1076-1107.

Guiso, Luigi, Paola Sapienza, and Luigi Zingales. 2004. "Does Local Financial Development Matter?” Quarterly Journal of Economics 119 (3):929-969.

Hahn, Jinyong, Petra Todd, and Wilbert Van der Klaauw. 2001. "Identification and Estimation of Treatment Effects with a Regression-Discontinuity Design.” Econometrica 69 (1):pp. 201-209.

Haines, Michael R. and ICPSR. 2010. "Historical, Demographic, Economic, and Social Data: The United States, 1790-2002." ICPSR study ICPSR02896-v3, available: http: / / dx . doi . org/10.3886/ICPSR02896, accessed 7 July 2010.

Hyslop, R. and Guido W. Imbens. 2001. "Bias from Classical and Other Forms of Measurement Error.” Journal of Business \& Economic Statistics 19 (4):pp. 475-481.

Imbens, Guido W. and Thomas Lemieux. 2008. "Regression discontinuity designs: A guide to practice." Journal of Econometrics 142 (2):615 - 635. 
James, John A. 1976a. "Banking Market Structure, Risk, and the Pattern of Local Interest Rates in the United States, 1893-1911." The Review of Economics and Statistics 58 (4):453-462.

—_ 1976b. "The Development of the National Money Market, 1893-1911." The Journal of Economic History 36 (4):878-897.

1978. Money and Capital Markets in Postbellum America. Princeton: Princeton University Press.

Jayaratne, Jith and Philip E. Strahan. 1996. "The Finance-Growth Nexus: Evidence from Bank Branch Deregulation.” The Quarterly Journal of Economics 111 (3):pp. 639-670.

Kaboski, Joseph P. and Robert M. Townsend. 2011. “A Structural Evaluation of a Large-Scale Quasi-Experimental Microfinance Initiative.” Econometrica 79:1357-1406.

Keehn, Richard H. and Gene Smiley. 1977. "Mortgage Lending by National Banks.” The Business History Review 51 (4):474-491.

King, Robert G. and Ross Levine. 1993. "Finance and Growth: Schumpeter might be right." Quarterly Journal of Economics 108 (3):717-737.

Lee, David S. and Thomas Lemieux. 2010. "Regression Discontinuity Designs in Economics." Journal of Economic Literature 48 (2):281-355.

Levine, Ross. 2005. Handbook of Economic Growth, vol. 1, chap. Finance and Growth: Theory and Evidence. Amsterdam: Elsevier, 865-934.

Maddison, Angus. 1995. Monitoring the World Economy 1820-1992. Paris: OECD Development Centre Studies.

Mbiti, Isaac and David N. Weil. 2011. "Mobile Banking: The Impact of M-Pesa in Kenya.” NBER Working Paper No. 17129.

Minnesota Population Center. 2004. "National Historical Geographic Information System.” Minneapolis, MN, University of Minnesota. Available: http://www.nhgis.org, accessed 7 July 2010.

Modigliani, Franco and Merton H. Miller. 1958. "The Cost of Capital, Corporation Finance and the Theory of Investment." The American Economic Review 48 (3):pp. 261-297.

Moulton, H. G. 1918. “Commercial Banking and Capital Formation: I." The Journal of Political Economy 26 (5):484-508.

$\mathrm{Ng}$, Chee K., Janet Kiholm Smith, and Richard L. Smith. 1999. "Evidence on the Determinants of Credit Terms Used in Interfirm Trade.” The Journal of Finance 54 (3):1109-1129. 
Nystrom, Paul H. 1915. The Economics of Retailing. New York: The Ronald Press Company.

Pascali, Luigi. 2011. "Banks and Development: Jewish Communities in the Italian Renaissance and Current Economic Performance." Barcelona GSE Working Paper 562, available: http: //research.barcelonagse.eu/tmp/working_papers/562.pdf.

Petersen, Mitchell A. and Raghuram G. Rajan. 2002. "Does Distance Still Matter? The Information Revolution in Small Business Lending." The Journal of Finance 57 (6):2533-2570.

Rajan, Raghuram G. and Luigi Zingales. 1998. "Financial Dependence and Growth." The American Economic Review 88 (3):559-586.

Sullivan, Richard J. 2009. "Regulatory Changes and the Development of the U.S. Banking Market, 1870-1914: A Study of the Profit Rates and Risk in National Banks." In The Origins and Development of Financial Markets and Institutions, edited by Jeremy Atack and Larry Neal. Cambridge University Press, 262-294.

Sylla, Richard. 1969. "Federal Policy, Banking Market Structure, and Capital Mobilization in the United States, 1863-1913.” The Journal of Economic History 29 (4):657-686.

Townsend, Robert M. and Kenichi Ueda. 2006. "Financial Deepening, Inequality and Growth: A Model-Based Quantitative Evaluation.” Review of Economic Studies 73:251-293.

White, Eugene Nelson. 1983. The Regulation and Reform of the American Banking System, 19001929. Princeton, NJ: Princeton University Press.

Wicker, Elmus. 2000. Banking panics of the Gilded Age. Cambridge: Cambridge University Press.

World Bank. 2009. World Development Report 2009: Reshaping Economic Geography. Washington, D.C.

Wright, Ivan. 1922. Bank Credit and Agriculture under the National and Federal Reserve Banking Systems. New York: McGraw Hill Book Company.

Young, Allyn A. 1924. "An Analysis of Bank Statistics For the United States." The Review of Economics and Statistics 6 (4):284-296. 
Table 1: County descriptive statistics

\begin{tabular}{|c|c|c|c|c|c|c|c|c|}
\hline \multirow[b]{2}{*}{ Year } & \multicolumn{4}{|c|}{ All rural counties } & \multicolumn{4}{|c|}{ Rural Union counties } \\
\hline & 1870 & 1880 & 1890 & 1900 & 1870 & 1880 & 1890 & 1900 \\
\hline \multirow[t]{2}{*}{ County population } & 11660 & 14703 & 17955 & 21330 & 16514 & 19848 & 23381 & 27105 \\
\hline & (13398) & (14889) & (17920) & $(28428)$ & (16036) & (17074) & (20295) & (36170) \\
\hline \multirow{2}{*}{$\begin{array}{l}\text { Total production } \\
\text { value per capita }\end{array}$} & 104.0 & 80.1 & 96.9 & 155.0 & 122.6 & 103.1 & 120.0 & 162.3 \\
\hline & $(82.5)$ & $(64.3)$ & $(77.2)$ & (312.7) & $(76.2)$ & $(67.1)$ & $(83.8)$ & $(97.5)$ \\
\hline \multirow{2}{*}{$\begin{array}{l}\text { Manufacturing } \\
\text { value per capita }\end{array}$} & 38.5 & 32.3 & 44.7 & 60.4 & 52.1 & 49.2 & 65.7 & 82.6 \\
\hline & $(66.2)$ & $(51.8)$ & (71.9) & $(97.2)$ & $(67.4)$ & $(62.9)$ & $(89.0)$ & $(106.7)$ \\
\hline \multirow{2}{*}{$\begin{array}{l}\text { Farm production } \\
\quad \text { value per capita }\end{array}$} & 65.5 & 47.8 & 51.0 & 94.5 & 70.4 & 53.9 & 53.7 & 79.7 \\
\hline & $(48.4)$ & $(37.8)$ & $(40.5)$ & (304.8) & $(39.8)$ & $(32.8)$ & $(28.4)$ & $(47.2)$ \\
\hline \multirow{2}{*}{$\begin{array}{l}\text { Fraction manuf. } \\
\text { in total value }\end{array}$} & 0.32 & 0.31 & 0.35 & 0.36 & 0.35 & 0.37 & 0.42 & 0.42 \\
\hline & $(0.28)$ & $(0.25)$ & $(0.28)$ & $(0.27)$ & $(0.24)$ & $(0.26)$ & $(0.28)$ & $(0.28)$ \\
\hline \multirow[t]{2}{*}{ Gini farm size } & 0.431 & 0.392 & 0.397 & 0.456 & 0.431 & 0.374 & 0.364 & 0.417 \\
\hline & $(0.171)$ & $(0.169)$ & $(0.153)$ & $(0.105)$ & $(0.139)$ & $(0.122)$ & $(0.119)$ & $(0.063)$ \\
\hline \multirow{2}{*}{$\begin{array}{l}\text { Fraction improved } \\
\text { farmland }\end{array}$} & 0.36 & 0.36 & 0.53 & 0.50 & 0.46 & 0.45 & 0.65 & 0.66 \\
\hline & $(0.24)$ & $(0.21)$ & $(0.23)$ & $(0.25)$ & $(0.25)$ & $(0.20)$ & $(0.20)$ & $(0.21)$ \\
\hline \multirow[t]{2}{*}{ Farm yield } & 15.34 & 11.00 & 7.61 & 10.66 & 14.07 & 10.02 & 6.84 & 9.19 \\
\hline & $(9.22)$ & $(8.10)$ & $(5.56)$ & $(7.58)$ & $(6.53)$ & $(6.55)$ & $(3.80)$ & (4.64) \\
\hline \multirow[t]{2}{*}{ Number of banks } & 0.41 & 0.57 & 1.06 & 1.09 & 0.82 & 1.08 & 1.68 & 1.78 \\
\hline & $(1.28)$ & $(1.46)$ & $(1.93)$ & $(1.99)$ & $(1.75)$ & $(1.95)$ & $(2.37)$ & $(2.50)$ \\
\hline \multirow[t]{2}{*}{ Distance to closest bank (km) } & 153.2 & 89.4 & 42.5 & 40.1 & 70.3 & 52.4 & 25.9 & 24.7 \\
\hline & (176.13) & (89.54) & $(37.37)$ & $(35.51)$ & $(82.31)$ & $(62.20)$ & (20.23) & $(20.60)$ \\
\hline \multirow[t]{2}{*}{ Banks per 1000 capita } & 0.015 & 0.021 & 0.051 & 0.042 & 0.029 & 0.036 & 0.063 & 0.057 \\
\hline & $(0.042)$ & $(0.050)$ & $(0.094)$ & $(0.073)$ & $(0.053)$ & $(0.059)$ & $(0.080)$ & $(0.064)$ \\
\hline \multirow{2}{*}{$\begin{array}{l}\text { Capital stock } \\
\text { per capita }\end{array}$} & 1.96 & 2.30 & 4.46 & 3.46 & 3.71 & 4.04 & 5.84 & 4.96 \\
\hline & $(6.23)$ & $(6.11)$ & $(8.18)$ & $(6.14)$ & $(8.22)$ & $(7.74)$ & $(8.19)$ & $(6.52)$ \\
\hline \multirow{2}{*}{$\begin{array}{l}\text { Loans and discounts } \\
\text { per capita }\end{array}$} & 2.74 & 3.93 & 10.41 & 10.52 & 5.20 & 6.63 & 13.68 & 14.84 \\
\hline & $(8.45)$ & $(10.75)$ & $(20.40)$ & (19.95) & (11.08) & (12.47) & (20.22) & (20.10) \\
\hline Counties & 2665 & 2745 & 2743 & 2745 & 1261 & 1301 & 1301 & 1301 \\
\hline
\end{tabular}

Notes: Standard deviations on in parentheses. The average is taken over counties and is unweighted. Values are in dollars from the census or national bank accounts and are not corrected for inflation/deflation (there was significant deflation between 1870-1880 as the US went back to a full gold backing of its currency). Rural Union counties are counties from Union or border states with an urban population of fewer than 50,000. Yield is the farm production value divided by the area improved farmland in a county, excluding extreme values driven low areas of improved farmland). 
Table 2: Log-likelihood estimates of optimal capital

\begin{tabular}{|c|c|c|c|c|c|}
\hline & All Rural & $\begin{array}{l}\text { All Rural } \\
\text { with } 1902\end{array}$ & Rural Union & $\begin{array}{c}\text { Rural Union } \\
\text { with } 1902\end{array}$ & $\begin{array}{l}\text { All Rural } \\
\text { with } 1902\end{array}$ \\
\hline $\ln \alpha$ & $\begin{array}{c}-15.24 * * * \\
(0.380)\end{array}$ & $\begin{array}{c}-12.94 * * * \\
(0.338)\end{array}$ & $\begin{array}{c}-16.51 * * * \\
(0.538)\end{array}$ & $\begin{array}{c}-15.16^{* * * *} \\
(0.497)\end{array}$ & $\begin{array}{c}-7.252 * * * \\
(0.0481)\end{array}$ \\
\hline $\ln \alpha_{1880}$ & $\begin{array}{r}-0.00241 \\
(0.0373)\end{array}$ & $\begin{array}{l}0.00455 \\
(0.0363)\end{array}$ & $\begin{array}{l}-0.0101 \\
(0.0439)\end{array}$ & $\begin{array}{l}-0.0136 \\
(0.0432)\end{array}$ & $\begin{array}{c}0.0961 * * * \\
(0.0343)\end{array}$ \\
\hline $\ln \alpha_{1890}$ & $\begin{array}{c}0.574 * * * \\
(0.0370)\end{array}$ & $\begin{array}{r}0.533 * * * \\
(0.0358)\end{array}$ & $\begin{array}{c}0.439 * * * \\
(0.0439)\end{array}$ & $\begin{array}{c}0.391 * * * \\
(0.0430)\end{array}$ & $\begin{array}{c}0.700 * * * \\
(0.0329)\end{array}$ \\
\hline $\ln \alpha_{1900}$ & $\begin{array}{c}0.270 * * * \\
(0.0392)\end{array}$ & $\begin{array}{c}0.535 * * * \\
(0.0370)\end{array}$ & $\begin{array}{c}0.214 * * * \\
(0.0460)\end{array}$ & $\begin{array}{c}0.444 * * * \\
(0.0438)\end{array}$ & $\begin{array}{c}0.764 * * * \\
(0.0328)\end{array}$ \\
\hline$\theta$ & $\begin{array}{c}0.810 * * * \\
(0.0396)\end{array}$ & $\begin{array}{c}0.602 * * * \\
(0.0353)\end{array}$ & $\begin{array}{c}0.983 * * * \\
(0.0552)\end{array}$ & $\begin{array}{c}0.868 * * * \\
(0.0512)\end{array}$ & \\
\hline$\sigma_{\eta}$ & $\begin{array}{c}1.767 * * * \\
(0.0398)\end{array}$ & $\begin{array}{l}1.688 * * * \\
(0.0363)\end{array}$ & $\begin{array}{c}1.464 * * * \\
(0.0429)\end{array}$ & $\begin{array}{c}1.349 * * * \\
(0.0384)\end{array}$ & $\begin{array}{l}1.642 * * * \\
(0.0352)\end{array}$ \\
\hline$\sigma_{\epsilon}$ & $\begin{array}{c}0.720 * * * \\
(0.0109)\end{array}$ & $\begin{array}{c}0.709 * * * \\
(0.0105)\end{array}$ & $\begin{array}{c}0.701 * * * \\
(0.0132)\end{array}$ & $\begin{array}{c}0.698 * * * \\
(0.0129)\end{array}$ & $\begin{array}{c}0.688 * * * \\
(0.0100)\end{array}$ \\
\hline$C^{T}$ & 17.041 & 22.772 & 15.846 & 21.196 & 24.359 \\
\hline$C_{25}^{T}$ & & 13.275 & & 12.366 & 14.154 \\
\hline Observations & 10804 & 10804 & 4998 & 4998 & 10804 \\
\hline Counties & 2745 & 2745 & 1262 & 1262 & 2745 \\
\hline
\end{tabular}

Notes: Estimates of the optimal capital equation $C_{c t}^{*}=\alpha \alpha_{t} P_{c t}^{\theta+1} \eta_{c} \epsilon_{c t}$ based on the panel using $C^{T}$ as the dividing line for entering with $\$ 50,0000$ in capital, and $C_{25}^{T}$ for entry with $\$ 25,000$ in the columns using 1902 . The full estimation details are in the separate S.2. The first column uses all rural counties as described in section 2, the second column uses all rural counties and the capital in 1902 for 1900, the third and fourth columns restrict the sample to Union and border states. The last column restricts $\theta$ to zero, removing any population scale effects. 
Table 3: Reduced form estimates of the effect of banks on log production per capita x 100

\begin{tabular}{|c|c|c|c|c|c|c|c|}
\hline \multicolumn{4}{|c|}{ Panel A: Capital stock per capita if capital $\geq 50$} & \multicolumn{4}{|c|}{ Panel B: Capital stock p.c. non-linear } \\
\hline \multirow[t]{2}{*}{ Capital p.c. } & \multirow[t]{2}{*}{$\begin{array}{c}6.12^{* * *} \\
(1.62)\end{array}$} & \multirow[t]{2}{*}{$\begin{array}{c}2.42 \\
(1.71)\end{array}$} & \multirow[t]{2}{*}{$\begin{array}{c}4.06^{* * * *} \\
(1.23)\end{array}$} & \multirow{2}{*}{ 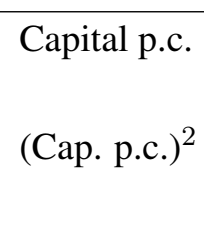 } & \multirow{2}{*}{$\begin{array}{c}17.0 * * * \\
(2.94) \\
-2.24 * * * \\
(0.71)\end{array}$} & \multicolumn{2}{|c|}{$\begin{array}{l}\text { Marginal effect at: } \\
C^{T} \quad C=200\end{array}$} \\
\hline & & & & & & $\begin{array}{c}14.9^{* * * *} \\
(2.39)\end{array}$ & $\begin{array}{l}-1.01 \\
(3.35)\end{array}$ \\
\hline Obs & 2,311 & 2,311 & 2,304 & Obs & 6,930 & & \\
\hline First Diff. & No & No & Yes & First Diff. & No & & \\
\hline County FE & No & Yes & No & County FE & Yes & & \\
\hline Year FE & Yes & Yes & Yes & Year FE & Yes & & \\
\hline
\end{tabular}

Panel C: Capital stock per capita if capital $\leq 50$

Panel D: Indicator for a bank if capital $\leq 50$

\begin{tabular}{lccc} 
Capital p.c. & $\begin{array}{c}21.8^{* * *} \\
(1.64)\end{array}$ & $\begin{array}{c}17.8^{* * *} \\
(1.42)\end{array}$ & $\begin{array}{c}12.2^{* * *} \\
(1.87)\end{array}$ \\
Obs & 7,082 & 7,082 & 4,926 \\
First Diff. & No & No & Yes \\
County FE & No & Yes & No \\
Year FE & Yes & Yes & Yes \\
\hline
\end{tabular}

Panel E: Neighbor comparison group

(next to a county with a bank with 50 capital)

\begin{tabular}{|c|c|c|c|c|c|c|}
\hline & \multicolumn{3}{|c|}{, } \\
\hline Sample: & $\begin{array}{c}\text { All } \\
\text { neighbors }\end{array}$ & $\begin{array}{l}\text { Only with } \\
C \leq 50\end{array}$ & $\begin{array}{l}\text { Only with } \\
C \leq 200\end{array}$ & Sample: & All & $\begin{array}{l}\text { One or } \\
\text { no banks }\end{array}$ \\
\hline Capital p.c. & $\begin{array}{c}6.06 * * * \\
(1.35)\end{array}$ & $\begin{array}{c}8.46 * * * \\
(3.02)\end{array}$ & $\begin{array}{c}6.22 * * * \\
(1.85)\end{array}$ & Capital p.c. & $\begin{array}{c}7.78^{* * * *} \\
(2.16)\end{array}$ & $\begin{array}{c}10.7 * * * * \\
(3.14)\end{array}$ \\
\hline Obs & 3,258 & 2,176 & 2,741 & Obs & 1,386 & 983 \\
\hline First Diff. & Yes & Yes & Yes & First Diff. & Yes & Yes \\
\hline County FE & No & No & No & County FE & No & No \\
\hline Year FE & Yes & Yes & Yes & Year FE & Yes & Yes \\
\hline
\end{tabular}

Notes: Capital stock per capita is measured in units of $\$ 50,000$ per 14,755 so measures the effect of adding a minimum size bank to a marginal county. Standard errors in parentheses. All regressions limit the sample to rural counties with populations greater than 1000 . Panel A only examines counties that have at least one bank and have a capital stock less than 500 and (normalized) capital stock per capita less than 5. Panel B also includes counties with no banks and allows the effect to be quadratic. Panel $\mathrm{C}$ restricts the sample to only counties with exactly one bank with capital less than 50 and capital stock per capita $\leq 5$. Panel D uses an indicator for having a bank and removes the capital stock per capita restriction in $\mathrm{C}$. Panels $\mathrm{E}$ and $\mathrm{F}$ find counties that were close to the margin between getting a bank and not. Panel E examines counties that are neighbors to counties with a 50 bank. The first column includes all neighbors, the second only neighbors that have no bank or a 50 bank, the third all counties with capital less than 200. Panel F includes only counties that have a 50 bank at some point during the period. 
Table 4: Banks and total production per capita

\begin{tabular}{|c|c|c|c|c|c|c|c|}
\hline & \multicolumn{7}{|c|}{ log Total production value per capita x 100} \\
\hline & \multicolumn{3}{|c|}{ Level with FE } & \multicolumn{2}{|c|}{ First difference } & \multirow{2}{*}{\multicolumn{2}{|c|}{$\begin{array}{c}\text { FE Diff. } \\
\text { Different effect } \\
\text { by state bank cap }\end{array}$}} \\
\hline & & $\begin{array}{l}\text { With } \\
\text { Lags }\end{array}$ & $\begin{array}{c}\text { No } \\
1902\end{array}$ & & $\begin{array}{c}1870-90 \\
\text { only }\end{array}$ & & \\
\hline $\begin{array}{l}\text { Excess capital } \\
\text { per capita } \\
\text { - Decade Lag }\end{array}$ & $\begin{array}{c}10.08 * * * \\
(2.642)\end{array}$ & $\begin{array}{c}9.872 * * * \\
(3.319) \\
9.291 * * * \\
(3.402)\end{array}$ & $\begin{array}{c}11.08 * * * \\
(2.032)\end{array}$ & $\begin{array}{l}5.952 * \\
(3.270)\end{array}$ & $\begin{array}{c}14.52 * * * \\
(5.331)\end{array}$ & $\begin{array}{c}16.67 * * * \\
(4.438)\end{array}$ & $\begin{array}{c}11.37 \\
(6.898)\end{array}$ \\
\hline $\begin{array}{l}\text { Optimal capital } \\
\text { per capita } \\
\text {-Decade Lag }\end{array}$ & $\begin{array}{c}3.435 * * * \\
(1.037)\end{array}$ & $\begin{array}{c}3.451 * * \\
(1.519) \\
3.955 * * * \\
(1.443)\end{array}$ & $\begin{array}{c}4.686 * * * \\
(0.794)\end{array}$ & $\begin{array}{c}3.046 * * \\
(1.424)\end{array}$ & $\begin{array}{c}4.494 * * \\
(1.857)\end{array}$ & $\begin{array}{c}2.538 * * * \\
(0.917)\end{array}$ & $\begin{array}{c}1.958 \\
(1.465)\end{array}$ \\
\hline \multicolumn{8}{|c|}{ Interaction of Excess cap. p.c. with } \\
\hline State min cap & in $1895 \times \mathrm{D}$ & $(1870)$ & & & & $\begin{array}{l}-0.350 \\
(0.358)\end{array}$ & \\
\hline State min cap & in $1895 \times \mathrm{D}$ & $(1880)$ & & & & $\begin{array}{l}0.818^{*} \\
(0.442)\end{array}$ & $\begin{array}{c}0.209 \\
(0.517)\end{array}$ \\
\hline State min cap & in $1895 \times \mathrm{D}$ & $(1890)$ & & & & $\begin{array}{c}-0.783 * * * \\
(0.236)\end{array}$ & $\begin{array}{l}0.0160 \\
(0.216)\end{array}$ \\
\hline State min cap & in $1895 \times \mathrm{D}$ & (1900) & & & & $\begin{array}{c}-0.860 * * \\
(0.384)\end{array}$ & $\begin{array}{c}-0.946 * * * \\
(0.338)\end{array}$ \\
\hline Observations & 4045 & 3143 & 7962 & 3092 & 2031 & 3269 & 2503 \\
\hline R-squared & 0.339 & 0.444 & 0.320 & 0.177 & 0.140 & 0.352 & 0.165 \\
\hline County FE & Yes & Yes & Yes & No & No & Yes & Yes \\
\hline Year FE & Yes & Yes & Yes & Yes & Yes & Yes & Yes \\
\hline Counties & 1087 & 1087 & 2127 & 1074 & 1074 & 876 & 876 \\
\hline
\end{tabular}

Notes: Excess capital stock per capita and optimal capital are measured in units of $\$ 50,000$ per 14,755 people and so measures the effect of adding a minimum size bank to a marginal county. Standard errors in parentheses are clustered at the state level. The estimates use the conditional mean of excess and optimal capital from the optimal capital stock estimation in table 2 . The regressions only include counties with a conditional mean with 15 of the dividing the transition capital. Excluding 1902 means that the conditional moments for optimal capital does not include information from banks entering with $\$ 25,000$ in 1902 . 
Table 5: Banks and the mix of production

\begin{tabular}{|c|c|c|c|c|c|c|c|c|c|c|}
\hline \multirow[b]{2}{*}{$\begin{array}{c}\text { Excess capital } \\
\text { per capita } \\
\text { - Decade Lag }\end{array}$} & \multicolumn{2}{|c|}{$\begin{array}{c}\log \text { Manufacturing } \\
\text { value per capita x } 100\end{array}$} & \multicolumn{2}{|c|}{$\begin{array}{l}\text { log Farm production } \\
\text { value per capita } x 100\end{array}$} & \multicolumn{2}{|c|}{$\begin{array}{l}\text { Percent Manuf. } \\
\text { in total production }\end{array}$} & \multicolumn{2}{|c|}{$\begin{array}{l}\text { Percent improved } \\
\text { farm land }\end{array}$} & \multicolumn{2}{|c|}{ Farm yield } \\
\hline & $\begin{array}{c}5.828 \\
(4.306)\end{array}$ & $\begin{array}{l}3.485 \\
(5.182) \\
-5.538 \\
(5.759)\end{array}$ & $\begin{array}{c}13.16 * * * \\
(3.273)\end{array}$ & $\begin{array}{c}15.79 * * * \\
(4.276) \\
15.86 * * * \\
(4.409)\end{array}$ & $\begin{array}{c}-1.737 * * \\
(0.674)\end{array}$ & $\begin{array}{c}-2.127 * * \\
(0.966) \\
-2.700 * * \\
(1.052)\end{array}$ & $\begin{array}{r}3.282^{* *} \\
(1.318)\end{array}$ & $\begin{array}{c}1.247 \\
(1.249) \\
-3.193^{*} \\
(1.694)\end{array}$ & $\begin{array}{c}0.839 \\
(0.780)\end{array}$ & $\begin{array}{c}0.701 \\
(0.709) \\
0.297 \\
(0.471)\end{array}$ \\
\hline $\begin{array}{l}\text { Optimal capital } \\
\text { per capita } \\
\text {-Decade Lag }\end{array}$ & $\begin{array}{l}2.440 \\
(2.076)\end{array}$ & $\begin{array}{c}2.043 \\
(2.424) \\
2.383 \\
(1.470)\end{array}$ & $\begin{array}{l}1.988 * * \\
(0.957)\end{array}$ & $\begin{array}{c}2.181 * \\
(1.191) \\
3.571 * * * \\
(1.272)\end{array}$ & $\begin{array}{c}0.256 \\
(0.301)\end{array}$ & $\begin{array}{c}0.0144 \\
(0.285) \\
-0.302 \\
(0.318)\end{array}$ & $\begin{array}{r}0.837 * * \\
(0.324)\end{array}$ & $\begin{array}{c}0.708 * * * \\
(0.231) \\
-0.142 \\
(0.373)\end{array}$ & $\begin{array}{c}-0.131 \\
(0.0963)\end{array}$ & $\begin{array}{l}-0.127 \\
(0.114) \\
0.0366 \\
(0.129)\end{array}$ \\
\hline Observations & 3997 & 3117 & 4062 & 3162 & 4045 & 3143 & 4068 & 3164 & 4058 & 3159 \\
\hline R-squared & 0.207 & 0.281 & 0.232 & 0.284 & 0.144 & 0.106 & 0.457 & 0.573 & 0.227 & 0.141 \\
\hline County FE & YES & YES & YES & YES & YES & YES & YES & YES & YES & YES \\
\hline Year FE & YES & YES & YES & YES & YES & YES & YES & YES & YES & YES \\
\hline Counties & 1086 & 1086 & 1087 & 1087 & 1087 & 1087 & 1087 & 1087 & 1085 & 1085 \\
\hline
\end{tabular}

Notes: Excess capital stock per capita and optimal capital are measured in units of $\$ 50,000$ per 14,755 people and so measures the effect of adding a minimum size bank to a marginal county. Standard errors in parentheses are clustered at the state level. All estimates use the conditional mean including banks in 1902 and all rural counties sample, restricting the sample to counties with a conditional mean of optimal capital stock within 15 of the transition capital. 
Table 6: Robustness to sample changes and distributional assumptions

\begin{tabular}{|c|c|c|c|c|c|c|}
\hline \multirow[b]{3}{*}{ Dependent Variable } & \multicolumn{4}{|c|}{ All rural counties } & \multicolumn{2}{|c|}{$\begin{array}{l}\text { Union rural } \\
\text { counties }\end{array}$} \\
\hline & \multicolumn{2}{|c|}{ using 1902} & \multicolumn{2}{|c|}{ not using 1902} & \multirow{2}{*}{$\begin{array}{c}\text { with } 1902 \\
1 \text { lag }\end{array}$} & \multirow{2}{*}{$\begin{array}{c}\text { no } 1902 \\
1 \text { lag }\end{array}$} \\
\hline & 1 lag & 2 lags & 1 lag & 2 lags & & \\
\hline \multirow{2}{*}{$\begin{array}{l}\text { Log total production } \\
\text { per capita } \times 100\end{array}$} & 10.077 & 19.164 & 11.084 & 21.416 & 8.890 & 10.574 \\
\hline & {$[0.000]$} & {$[0.002]$} & [0.000] & {$[0.000]$} & {$[0.001]$} & [0.001] \\
\hline \multirow{2}{*}{$\begin{array}{l}\text { Log manufacturing prod. } \\
\text { per capita } \times 100\end{array}$} & 5.828 & -2.053 & 3.706 & -9.600 & 10.560 & 10.308 \\
\hline & [0.182] & {$[0.828]$} & [0.429] & {$[0.345]$} & {$[0.020]$} & [0.007] \\
\hline \multirow{2}{*}{$\begin{array}{l}\text { Log farm production } \\
\text { per capita } \times 100\end{array}$} & 13.162 & 31.644 & 13.599 & 33.169 & 16.198 & 14.415 \\
\hline & {$[0.000]$} & {$[0.000]$} & [0.000] & {$[0.000]$} & {$[0.002]$} & [0.002] \\
\hline \multirow{2}{*}{$\begin{array}{l}\text { Percent manufacturing } \\
\text { in total production }\end{array}$} & -1.737 & -4.826 & -1.791 & -5.673 & -1.716 & -0.893 \\
\hline & {$[0.013]$} & {$[0.003]$} & [0.049] & [0.001] & [0.046] & {$[0.320]$} \\
\hline \multirow[t]{2}{*}{ Gini of farm size } & -0.573 & 7.164 & -0.651 & 6.504 & -1.137 & -0.898 \\
\hline & {$[0.267]$} & {$[0.000]$} & {$[0.127]$} & {$[0.000]$} & {$[0.020]$} & {$[0.012]$} \\
\hline \multirow{2}{*}{$\begin{array}{l}\text { Percent improved } \\
\text { farm land }\end{array}$} & 3.282 & -1.946 & 4.580 & 2.766 & 5.183 & 4.873 \\
\hline & {$[0.016]$} & {$[0.480]$} & {$[0.001]$} & {$[0.218]$} & [0.003] & [0.002] \\
\hline \multirow[t]{2}{*}{ Farm yield } & 0.839 & 0.998 & 0.665 & 0.856 & 1.663 & 1.360 \\
\hline & {$[0.288]$} & [0.357] & [0.333] & {$[0.325]$} & {$[0.262]$} & [0.310] \\
\hline Observations & 4045 & 3143 & 7962 & 6138 & 3021 & 3644 \\
\hline Counties & 1087 & 1087 & 2127 & 2127 & 785 & 972 \\
\hline
\end{tabular}

Notes: p-values in brackets, testing the combined effect of both lags of excess capital stock per capita. All columns include counties with a conditional mean within 15 of the entry point. The first two columns show the results including the rule change in 1902; the next two columns use the conditional mean based on the optimal capital stock estimation that does not use the extra information from the rule change. The fifth and sixth columns use only rural Union counties (see footnote 10). All regressions include county fixed effects, time effects, and cluster at the county level. 
Figure 1: Distribution of national bank capital stock in U.S. counties

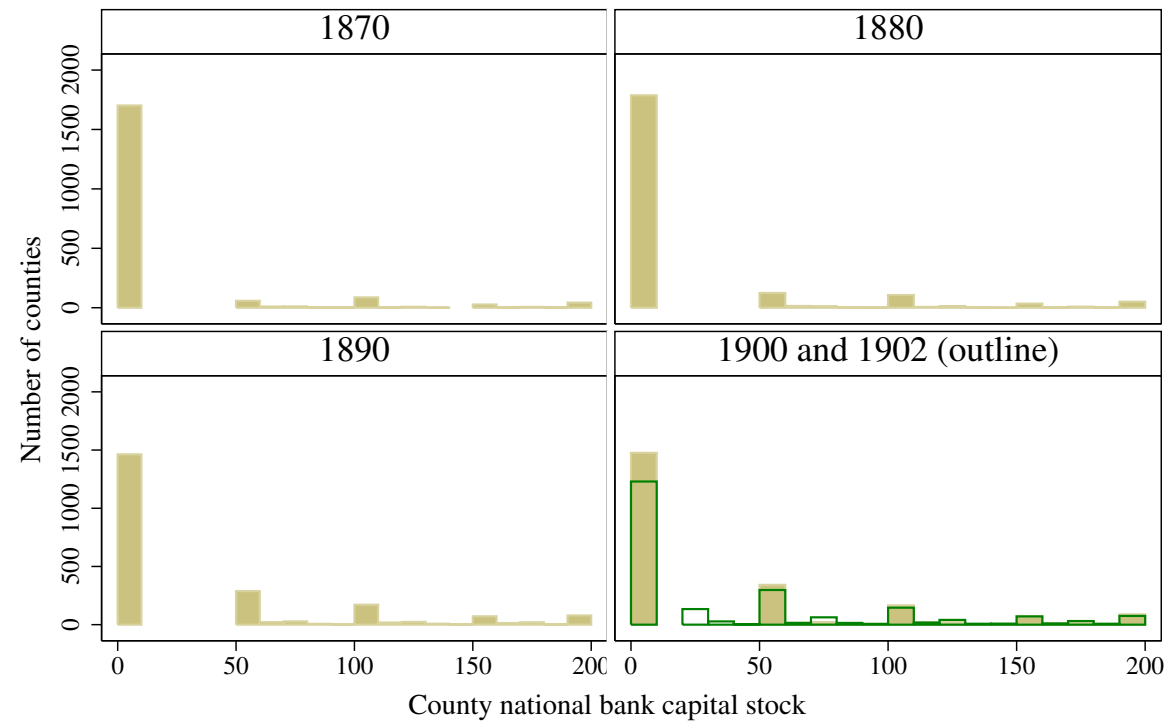

Notes: Shows the number of counties in each year with total capital stock (in $\$ 1000$ s) in each $\$ 5,000$ wide bin. Note the large number of counties with zero capital stock, and so no banks. The bottom right panel shows both the distribution in 1900 and in outline the distribution in 1902 after Congress reduced the minimum capital stock to $\$ 25,000$. The number of counties with exactly 50 capital stock and the opening of new banks at 25 between 1900 and 1902 indicates that the minimum capital stock was a binding constraint.

Figure 2: National bank capital stock in U.S. counties
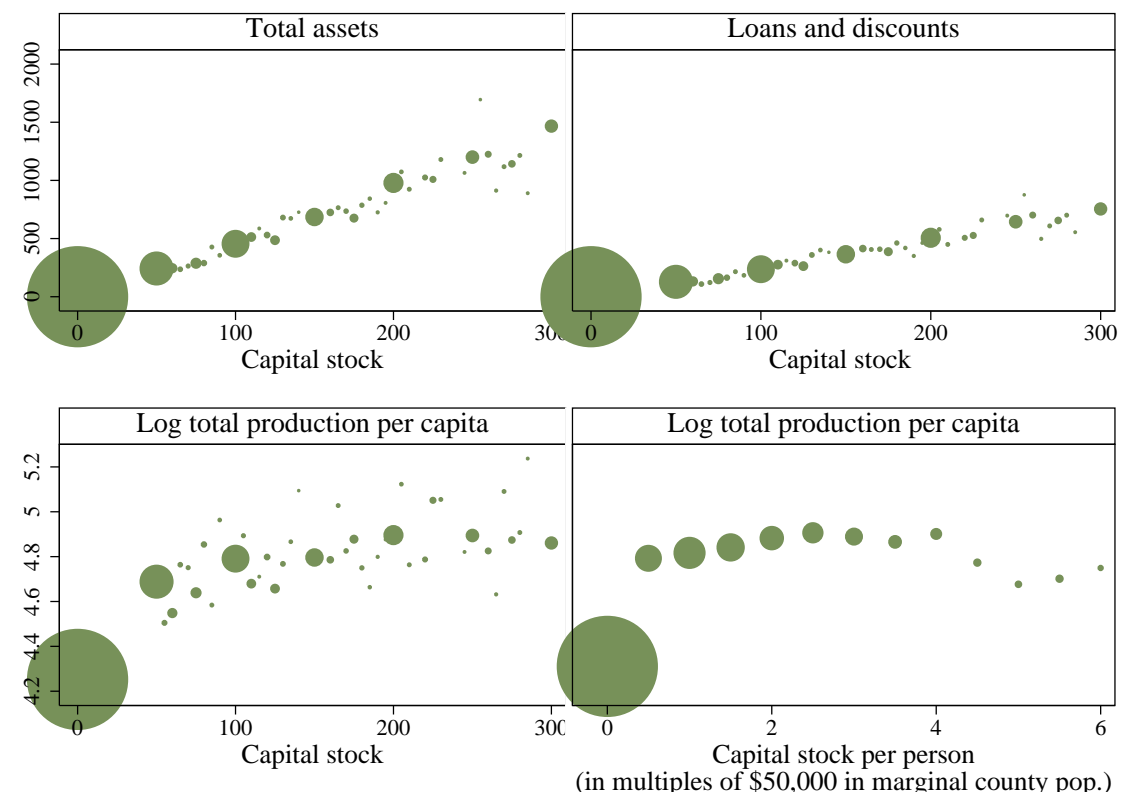

Notes: The size of the marker is proportional to the number of counties in the bin. Each dot for the average liabilities, loans, and log production per capita is the average of the counties that fall in a $\$ 5,000$ wide bin. Overall year effects are first removed from log total production per capita. In the bottom right panel capital stock per person is measured as (capital/population) $*($ marginal county population / 50). 
Figure 3: Draws from optimal capital and county characteristics
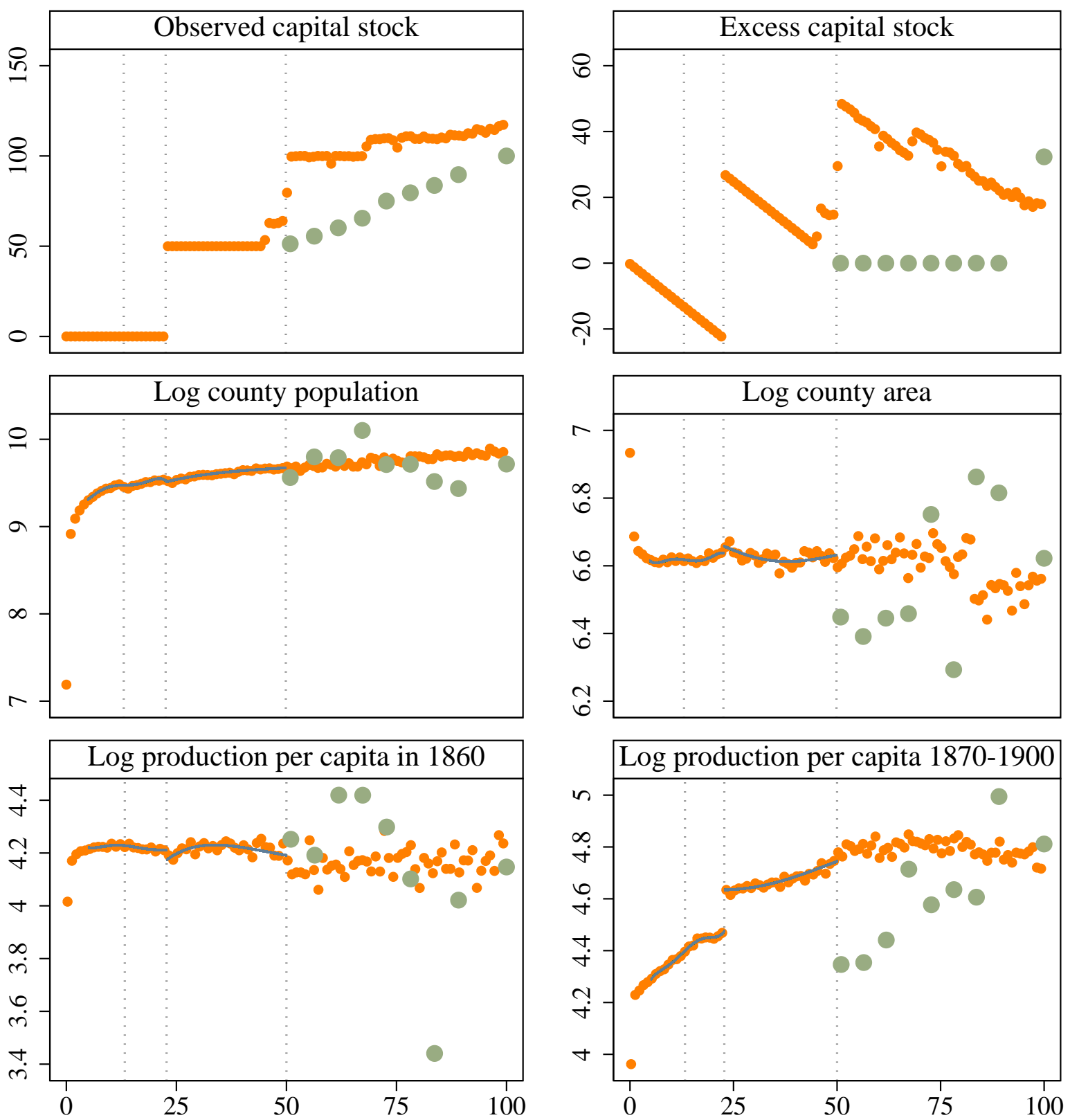

Optimal capital stock

Notes: Shows the relationship between the estimated capital stock banks wanted to open with (optimal capital stock) and observable outcomes. Each dot is the result of multiple draws from the specific optimal capital distribution for each county in each year as estimate using equation 1 with the estimates in table 2 . Each dot represents the average of the characteristics of the counties with draws within a 1 capital stock wide bin. Actual capital is zero if banks are below the entry threshold $\left(C^{T}\right)$ and 50 if banks enter at the minimum capital. Predetermined characteristics such as the Distance to St. Louis, the county area, and production in 1860 vary approximately continuously with the optimal capital. Production during the period jumps discontinuously as banks enter. Overall year effects are first removed from log total production per capita to deal with price changes. The larger light marks are the 5 capital wide bins for the counties with actual capital greater than 50 . 